DOI: https://doi.org/10.32653/CH174912-937

Lyudmila B. Gmyrya,

Dr. Sci. (History), Leading Researcher

Institute of History, Archeology and Ethnography

Dagestan Federal Research Center of RAS, Makhachkala, Russia

lgmyrya@mail.ru

\title{
THE RUBAS FORTIFICATION OF THE MID 6TH CENTURY: FEATURES OF THE STRUCTURE OF THE EASTERN FACADE OF WALL 2
}

\begin{abstract}
The Rubas fortification is a unique complex of stone military-engineering structures, built in the lower reaches of the River Rubas, $20 \mathrm{~km}$ west of the Caspian Sea coast and the same distance southwest of the Derbent Pass. In terms of the main indicators (monumentality and functional orientation), it belongs to a series of defensive lines of the Western Caspian region, erected by Persia with the assistance of Byzantium during the era of the Great People's Migration. Typologically and chronologically, it has analogies with the fortress structures of Derbent, dating back to the 6th century. Its uniqueness is justified by the presence of monumental military-engineering structures of various parameters in terms of design and layout, united by construction links into a single object. Each structure carried a separate function, complementing the general tasks of a defensive nature. The structure of the eastern facade of Wall 2 is of combined nature, since it comprises of several different types of sections. The present article considers the features of building techniques for the construction of the facade of a monumental wall of a defensive structure, which are distinguished by a main direction. The purpose of this study is to analyze engineering solutions and to determine the functional tasks of each object included in the eastern facade of Wall 2. Research methods include detail analysis of techniques of erecting the eastern facade of Wall 2, substantiation of presence of various structure parts of its sections and identification of functional purpose of the synthesis system of the facade's structure of the main wall. Analysis of materials of the structurally complex defensive object of the Rubas fortification of the middle of the 6th century, which is the main monumental Wall 2, namely its outer eastern facade, shows that the complex of engineering solutions of this structure was mainly due to the volume of external loads and the strategy of assault on a particular enemy, which at that time were the nomadic Turkic-speaking tribes who used Derbent passage for military operations in the Caucasus and the Middle East.
\end{abstract}

Keywords: Rubas fortification; East Caucasus; Main Wall 2; structure of the eastern facade; Sasanian Iran.

(C) Gmyrya L.B., 2021

(C) Daghestan Federal Research Centre of RAS, 2021 
DOI: https://doi.org/10.32653/CH174912-937

Гмыря Людмила Борисовна, д.и.н., ведущий научный сотрудник Институт истории, археологии и этнографии Дагестанский федеральный исследовательский центра РАН, Махачкала, Россия lgmyrya@mail.ru

\section{РУБАССКАЯ ФОРТИФИКАЦИЯ СЕРЕДИНЫ VI В.: ОСОБЕННОСТИ КОНСТРУКЦИИ ВОСТОЧНОГО ФАСАДА СТЕНЫ №2}

Аннотация: Рубасская фортификация - это уникальный комплекс каменных военно-инженерных сооружений, аналогов которому нет. Он возведен в низовьях р. Рубас, в 20 км к западу от побережья Каспийского моря и на таком же расстоянии к юго-западу от Дербентского прохода. По основным показателям (монументальность и функциональная направленность) он относится к серии заградительных рубежей Западного Прикаспия, возведенных Персией при содействии Византии в эпоху Великого переселения народов. Типологически и хронологически - сопоставим с крепостными сооружениями Дербента, датируемыми VI в. Его уникальность обусловлена наличием разнохарактерных по конструкции и планировке монументальных военно-инженерных сооружений, объединенных строительными связками в единый объект. Каждое сооружение несло обособленную функциональную нагрузку, дополняя общие задачи оборонительного характера. Особым своеобразием структуры и конструкции отличается восточный фасад стены № 2. Структура восточного фасада стены № 2 носит комбинированный характер, т.к. включает несколько разнотипных участков. В данной статье впервые рассматриваются особенности конструктивных приемов возведения внешнего фасада монументальной стены оборонительного сооружения, отличающейся магистральной направленностью. Цель данного исследования состоит в проведении анализа инженерных решений и в определении функциональных задач каждого объекта, включенного в восточный фасад стены № 2. Методика исследования включает детальный анализ технологических приемов возведения восточного фасада стены №2, обоснование наличия разнотипных по конструкции составляющих его участков и определение функциональной обусловленности синтезной системы конструкции внешнего фасада магистральной стены. Анализ материалов структурно сложного оборонительного объекта Рубасской фортификации сер. VI в., каким является магистральная монументальная стена № 2, а именно ее внешний восточный фасад, показывает, что комплекс инженерных решений этого сооружения был обусловлен главным образом объемом внешних нагрузок и стратегией штурма конкретного противника, каким в это время выступали кочевые тюркоязычные племена, использовавшие Дербентский проход для военных операций в Закавказье и на Ближнем Востоке.

Ключевые слова: Рубасская фортификация; Восточный Кавказ; магистральная стена № 2; структура восточного фасада; Сасанидский Иран.

(C) Гмыря Л.Б., 2021

(C) Дагестанский федеральный исследовательский центр РАН, 2021 
The archeological site "Rubas Fortification" was discovered by local residents of the village of Kommuna of the Derbent district of the Republic of Dagestan in 2014.

The excavations of this military-engineering structure (2014, 2016-2018, 2020) have been carried out by the Rubas Archaeological expedition of the Institute of History, Archeology and Ethnography of the Russian Academy of Sciences.

Studies have shown that structurally the Rubas fortification consists of several military engineering structures that differ in layout, design, construction technology and functional purpose. The excavations in 2020 revealed the following structures: 1) Main Wall 2; 2) Wall 3; 3) Structure 5 (platform); 4) Structure 6 (annex); 5) arched structure; 6) Wall 1 [2, p. 1101-1110] [Fig. 1; 2; 16-21] .

Of particular interest is the use in one defensive object of different types of building techniques, which is due to different functional purposes of each object.

The present article discusses the design features of the eastern facade of the Main Wall 2, which includes 5 independent sections, built according to the principle of symmetry [Fig. 15 A-B]. The purpose of the study is to analyze engineering solutions and to determine the functional tasks of each site included in the eastern facade of Wall 2.

Excavations and restoration of construction sites at the Rubas fortification are complicated by the extensive damage in 2014, inflicted by the local residents in order to excavate large stone blocks for further use as building material [Fig. 1; 16-17].

Survey excavations in 2014 identified small sites of 3 structures. On the northern slope of the pit with large fragments of stones there was a part of the southern section of the Main Wall 2 (orientation E-W), as well as a small section of Wall 3, built into its eastern facade at an angle of 900. On an undisturbed area there was the upper level of the arched structure with anoverlap of the passage of 3 solid stone slabs with a length of 2.6-2.8 m. A small section of Wall 1, attached from the north to the western basesupport of this structure, was also identified [1, pp. 63-64].

In 2014, in the piles of dirt left by the local residents after the excavation of stone blocks from structures by heavy machinery, fragments of a unique ceramic vessel with relief Arabic inscriptions were revealed, which is a quote from a Surah of the Koran: "It is out of the mercy of my Lord to test me whether I will be grateful or unfaithful" [4, pp. 28-35]. Any analogies of the use of quotations from the Koran on household items of the Caucasian and Caspian regions are unknown to us.

In 2016-2018, excavations uncovered the full level of the arched structure and Wall 1, attached to it from the north [Fig. 1,5-6; 2,2-3]. The main Wall 2, oriented in the direction of the NW-SE, was also revealed almost completely [Fig. 1,1; 2,1]. Studies of Wall 3, attached to Wall 2,continue [1, pp. 64-69].

On the basis of the section of Wall 3 with a length of $5 \mathrm{~m}$ excavated in 2014, 2018, its layout was determined as linear, oriented in the $\mathrm{W}-\mathrm{E}$ direction. According to the results of excavations in 2018, part of the blocks of this wall was in the position of a "fan spread", which was conditioned by powerful tectonic movements, as determined by seismologists [5, pp. 91-103; 6, pp. 91-103]. 
Excavations of 2020 revealed 2 new military-engineering objects - the structure of a stepped design 6, built from north to the main Wall 2 [Fig. 1,4; 2,7; 3,1], and a platformlike structure [Fig. 1,3; 2,6; 18, 19,2 and 21] with an inclination of the surface of 22.50to east [2, p. 1103-1106, 1109].

Further investigations in 2020 of Wall 3 established its rounded shape with a bend from the W-E line to the N-E line [Fig.1,2; 2,4; 16,1; 17; 19,1], which had been formed by the technology of shifting blocks in the masonry at a certain angle (fan shift) and the presence of a stepped structure of the northern facade [2, pp. 1106-1109]. The formation of the roundness of this wall must be recognized as a unique construction technology, given that the desired shape of the structure was achieved by massive stone blocks of elongated forms [Fig. 20].

The analysis of the materials of the excavations of the Rubas fortification shows that the central position in its structure is occupied by Wall 2. This is the longest structure, stretched in the direction of the NW-SE. To the west of it there are two objects - the arched structure and the Wall 1 attached to it. Three other structures of this complex - Wall 3, the Stepped structure (6) and Structure 5 (platform) - occupy an eastern position relative to Wall 2 [Fig. 1; 2].

Wall 2 islaid with the use of rubble masonry (emplekton, ashlar and rubble). The facades (east and west) are built of large stone blocks (shell rock, sandstone); the interwall filling includes rough stone, river pebbles of various sizes and compacted soil. The technology of laying blocks in the wall is different - bed and "opus quadratum" masonry. The width of the wall is $3.5 \mathrm{~m}$ [Fig. 1,1; 2,1].

The western facade of Wall2 was examined for $26 \mathrm{~m}$ [Fig. 2,1]. According to the results of excavations in 2018, its southern section continues towards the left bank of the Rubas River, which has low elevations ( $\pm 42.0 \mathrm{~m}$ ) in comparison with the right bank, which occupies a dominant position on the terrain $( \pm 85.45 \mathrm{~m})$. The northern section of the western facade of Wall 2 within the excavation of 2018 is interrupted, but it likely has a continuation at the lower level of the masonry, overlapped by powerful mudflow layers [1, pp. 64-65].

The eastern facade of Wall 2 was uncovered as a result of 2020 excavations for $17.5 \mathrm{~m}$ [Fig. 2,1]. From south, it is bounded by Wall 3 built into it, oriented in the transverse direction $\mathrm{W}-\mathrm{E}, \mathrm{NW}$, from which the northern facade of the stepped structure and semicircular configuration has preserved. The southern facade of the Wall 3 has not yet been discovered, as well as the southern section of the eastern facade of the Wall 2.

The territory where the southern section of the eastern facade of Wall 2 could have been located was subjected to large-scale destruction in 2014, as mentioned above. Local residents, who accidentally discovered the upper levels of the masonry of Wall 2 , removed a significant number of massive stone blocks from the structure and took them to the village of Kommuna for construction purposes. Some of the blocks were sawn into small fragments. During the investigation of the site in 2014, a pit measuring $9 \times 7.5 \mathrm{~m}$ and $3 \mathrm{~m}$ deep filled with large fragments of stones, white lime mortar and soil was recorded on the territory of the destroyed fortification [Fig. 1,1]. We managed to preserve 13 whole stone blocks and 17 samples of large stone fragments, which survived 
the sawing. They were numbered, described, photographed and placed for safekeeping in the secondary school of the Rubas village; all data about them were published.

According to the results of excavations in 2020, the total length of the examined section of the Wall 2 is $28 \mathrm{~m}$.

The western facade of Wall 2 has preserved to a height of $2.5 \mathrm{~m}$. In its structure, there are 3 sections with different types of masonry: northern (bed masonry of elongated blocks of medium thickness); central ("opus quadratum" masonry of blocks of different sizes, including $2 \mathrm{~m}$ long, with upper level laid with bed masonry); southern (bed masonry of thickened blocks installed with the short side outwards). The western facade of Wall 2 was formed without ledges. The maximum height of the western facade of Wall 2 survived at the level of 10 rows of bed masonry.

The eastern facade of Wall 2 has a height of $2.4 \mathrm{~m}$ [Fig. 5,2; 6,2; 15A]. Visually, on the eastern facade of Wall 2, five separate sections can be distinguished, varying in design and construction technology (sections A, B, C, D, E) [Fig. 15B]. The junction points are performed with various construction techniques. The design features of these objects reveal the functional orientation of each of them.

Section A. The section was investigated during the conservation excavations of 2014. It is located at the southern end of the eastern facade of Wall 2. The length of the section is $2.6 \mathrm{~m}$. 8 rows of bed masonry were revealed. The section is bounded from the south by the Wall 3 built into it [Fig. 15B].

Features of the construction technology: the masonry is laid in a stepped manner; the width of the steps of the 4 lower rows of the masonry is noticeably wider than the steps of the upper rows; the blocks of the lower rows have non-standard sizes and shapes, as well as poor-quality dressing [Fig. 5-6; 16].

It was not possible to link these features with the technical necessity, due to the littleavailable data. The eastern facade of the massive wall was defined by the external line of defense, unlike the western facade. However, its stepped design did not fit into a rational approach aimed at complicating the storming of this structure by the enemy. The only reason that could explain the stepped shape of this structure was the nature of the expansion of the support of a massive object, which increased its stability.

The reason for this type of masonry of the southern section of the eastern facade of Wall 2 became clear in 2020, when the rounded shape of the northern facade of Wall 3 was revealed and a system of its attachment to Wall 2 was identified. Analysis of the construction remains of Wall 3 showed that the connection of this structure to Wall 2 was made by its lower level, which had a fan shape $2.5 \mathrm{~m}$ wide [Fig. 16].

Section B. Investigated in 2014, 2016. It connects from the north to Section A. The length is $2.1 \mathrm{~m}$, the preserved height is $2.4 \mathrm{~m}$. This object was built using 2 types of masonry - bed and "opus quadratum" [Fig. 15B].

Features of the construction technology: the upper 3 rows of masonry and the lower 4 rows were laid in a bed technique and a stepped method, similar to Section A. Between the upper and lower levels of the masonry there is an inset of 4 stone blocks installed using the "opus quadratum" technique [Fig. 5-6].

The functional purpose of using the "opus quadratum" masonry on this section of Wall 2 was not initially associated with a constructive necessity, but rather an aesthetic 
look. Carved images on the outer surface of the headers were revealed. On one block there is a profile image of a horse; on the other, probably, an image of a settlement plan and a defensive wall. The images placed on the front surface of large blocks were interpreted as a kind of manifestation of the main ideological symbols of the population living within the limits of the monumental defensive structure in the valley of the Rubas River.

According to the available data of 2014 and 2016, it was not possible to consider this section of the facade as a necessary structural detail that strengthened Wall 2. The connection of both structures was carried out without a solid abutment of the blocks and vertical consistency with the formation of a slit space filled with thick river pebbles. The two lower levels of masonry of both sections formed a single platform for this part of the facade of Wall 2 [Fig. 2,1].

Section C. Investigated in 2016-2018, 2020. Attached from the north to Section B. The length is $7.1 \mathrm{~m}$, the preserved height is $2.6 \mathrm{~m}$. 11 rows of bed masonry were revealed [Fig. 15B].

Features of the construction technology: stone blocks are installed in the wall quitecarefully, the rows of masonry are smooth, their horizontality is clear. The blocks are thoroughly dressed, all about the same thickness. The lower levels of the masonry include several large blocks with a length of 1.2-1.6 m. The blocks are also installed in the wall in a stepped manner, but their width decreases towards the north [Fig. 3,2; $4,2 ; 5,2 ; 6,2]$.

The attachment of structures $\mathrm{B}$ and $\mathrm{C}$ was carried out by joining the 6 upper rows and embedding the 5 lower rows of masonry into the structure [Fig. 15B].

The reason for such a complex design solution for the formation of the eastern facade of Wall 2, which includes diverse structures, remain unclear according to the data obtained.

However, in 2020, in search of a continuation of Wall 2 to the north, a $5.7 \mathrm{~m}$ long building was identified, conventionally identified as a "stepped structure" $6[2$, pp. 1103-1106]. Its structure included 2 different types of sections: D and E. Moreover, both sections had a constructive analogy with the objects of this facade identified earlier [Fig. 15B; 3,2; 5,2; 6,2].

Section D. Investigated in 2020. Attached from the north to the Section B. The length is $2.7 \mathrm{~m}$, the preserved height is $2.44 \mathrm{~m}$. This structure was built using 2 types of masonry - bed and "opus quadratum" [Fig. 15, B].

Features of the construction technology: the upper 4 rows of masonry and the lower 3 rows are laid by a bed technique and a stepped method. Between the upper and lower levels of the masonry there is an inset of 5 stone blocks installed using the "opus quadratum" technology [Fig. 13; 9-10; 11A-B]. The design of Section D is similar to the design of Section B. However, the blocks of the "D"section differ in larger dimensions [Fig. 15B].

The joining of Sections $C$ and $D$ is based on the principles of mutual embedding of stone blocks into the masonry system of each of them [Fig. 11A; 13].

Section D is extended to the east by $0.8 \mathrm{~m}$ relative to the lower level of the main line of the eastern facade of Wall 2 [Fig. 3-10; 12; 14]. 
Section E. Investigated in 2020. Attached from the north to Section D. The length is $3 \mathrm{~m}$, the preserved height is $1.7 \mathrm{~m}$ [Fig. $15 \mathrm{~B}$ ].

Features of the technology: built with bed masonry in a stepped manner (8 levels of masonry). The blocks in the masonry are thoroughly dressed, installed in even horizontal rows. Blocks of medium and large sizes are included. One block of the $5^{\text {th }}$ row of masonry had a length of $1.95 \mathrm{~m}$, the other (7th row of masonry) was opened for $1.9 \mathrm{~m}$, its northern end goes under the northern side of the excavation. The width of the steps of 3-7 levels of masonry is 0.3-0.4 m [Fig. 7-10; 12; 13]. Technological methods of installing blocks in masonry aimed at changing its direction to the northeast and possible rounding of the northern facade were recorded [Fig. 9; 13].

The attachment of Section E with Section D was carried out by joining its 3 upper rows of masonry. The four lower rows of masonry of both sections (D and E) formed a single platform for this part of the facade of Wall 2 [Fig. 9; 10; 13].

To a certain extent, Section $\mathrm{E}$ of the eastern facade of Wall 2 repeats the shape and design of Section A, but it survived in larger quantities [Fig. 15B].

On the eastern facade of Wall 2, the symmetry of the design techniques is visible, as it seems, due to an accurate design calculation [Fig. 15B]. Based on the analysis of the available materials of the excavations of 2014, 2016-2018, 2020, certain patterns in the design of the eastern facade of the main Wall 2 were revealed.

Before the discovery in 2020 of 2 new sections of the eastern facade of Wall 2 (D and E), it was not possible to consider the regularities of its design. At this stage of the study, it is necessary to note the essential indicators of the construction of Wall 2 and to identify the functional tasks of each of the sections of this structure.

The central position in the construction of the eastern facade of Wall 2 is occupied by Section C. It is not only the longest in structure, but also the most thoroughly constructed. It also differs from other sections by the uniformity of the building technology [Fig. $15 \mathrm{~B}]$.

The section with a uniform masonry $\mathrm{C}$ is structurally connected with two other sections, built according to the same design. On the south side, it is adjoined by Section B with a length of $2.1 \mathrm{~m}$, on the north side - Section D with a length of $2.7 \mathrm{~m}$ [Fig. 15B]. They are also laid with bed masonry of a stepped design.Their typological identity is based on the inclusion in the structure of blocks, laid according to the «opus quadratum» system. Section B includes 2 blocks, laid on edges of the long side and 2 blocks laid on the edge of the lateral sides. Section D includes 2 blocks, laid on edges of the long side, but 3 blocks laid on the edge of the lateral side. The blocks of both sections installed using the "opus quadratum" method were revealed at the same level.

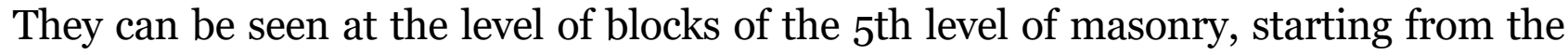
lower row. Constructional connection of the both sections (B and D) is carried out with the lateral sides of Section $C$ through blocks installed on the edge of the lateral side. The smaller length of Section B in relation to Section D is due to the presence of only 2 such blocks in contrast to the 3 blocks of Section D [Fig. 15B].

Sections A and $\mathrm{E}$ close the construction of the eastern facade from the north (E) and south (A). In length, both sections differ slightly: "A" - 2.6 m; "D" - 3 m [Fig. 15B]. However, Section A, as noted, suffered significant destruction in 2014 during the 
unauthorized excavation of large stone blocks, which led to the formation of a pit with a depth of over $3 \mathrm{~m}$.

The identity of the structure of Sections B and D of the eastern facade of Wall 2 and the same technology of connection of these sections with the central Section C indicates the need for their location in the construction system of the eastern facade of Wall 2. Connection of sections by means of blocks installed with the side part outward, with a section of Wall C, which went deep into the structures of the eastern facade, significantly strengthened the masonry and reduced the possible deformation of the central Section C of Wall 2. Sections B and D functioned as a kind of fasteners that protected Section $\mathrm{C}$ from deformation. Moreover, given the presence in Section D of 3 copies of blocks installed with the side part outward, and 2 of the same blocks in Section B, the threat of possible deformation of Section $\mathrm{C}$ came mostly from the north.

Section A of the eastern facade of Wall 2, as noted, served as a junction for Wall 3, i.e. it was a kind of buffer holding its considerable mass. The connection of 2 walls ( 2 and 3) was of a complex nature, given the rounded shape of the northern facade of Wall 3 , the stepped design of its construction and the fan-shaped method of installing blocks into the wall.

Section $\mathrm{E}$ of the eastern facade of Wall 2 may have had the same function as Section A, i.e. it was a buffer. Its full shape has not yet been restored, but some indicators of its design make it possible to assume that there was a certain rounding of this structure at the northern end [Fig. 9; 12]. In addition, groundwater that emerged at a depth of $2.9 \mathrm{~m}$ made it hard to reveal the full length of Section $\mathrm{E}$ along the $\mathrm{W}-\mathrm{E}$ line. According to the 2020 excavations, Section E protrudes from the line of the lower rows of the masonry of Section B to the east by $1.9 \mathrm{~m}$ [Fig. 12]. Section D is likely a part of a rather bulky structure included in the structure of the eastern facade of Wall 2.

It should be noted that significant deformation of structures was recorded in Sections D and E [Fig. 13]. There is a deep shift (slope) of all masonry levels to the south on Section D, including the "opus quadratum" masonry. On Section E, the masonry deformation was recorded only at levels $5-6$, counting from the upper rows, in the places of connection to the section $\mathrm{D}$. The reason for the recorded deformation of these sections is yet unclear (possible earthquake, groundwater, destruction of a wartime character). However, the analysis of the construction of the eastern facade of Wall 2 shows that in the process of deformation of Sections D and E, the northern edge of Section $\mathrm{C}$ was also affected. The masonry of this part of Section $\mathrm{C}$ for $2.9 \mathrm{~m}$ at almost all levels received an inclination to the north. It seems that there is a depression in the junction of Sections C and D, because the direction of deformation of these sections' structures is oncoming.

The analysis of the structure of the eastern facade of Wall 2 and the structure of the construction objects included in it shows that their location in the system of the eastern facade of Wall 2 is due to specific defensive tasks. Engineering solutions for the construction of the eastern facade of Wall 2 are original, and have not been recorded in the practice of other regions (Caucasian, Crimean, Transcaucasian) [7, pp. 39-46; 8, pp. 267-287; 9, pp. 441-465; 10, pp. 357-390; 11, pp. 227-246; 12, pp. 170-200]. 


\section{Conclusion}

The design and construction technology of the facade of the Main Wall 2 of the Rubas fortification testify to the high degree of development of military engineering in Sasanian Iran of the middle 6th century.Terrain features, strategic and tactical tasks of an extended defensive facility were taken into consideration when building these structures.

A system of multidisciplinary design of large-scale objects was used. Each object has a unique layout. A variety of constructive junctions between defensive objects of different profiles was developed, providing the defenders of the structure the opportunity to maneuver freely (objects are embedded one into another, the junctions of the objects with plates in entry points). Construction methods were developed to connect different types of objects into a single line of defense.

Both the latest methods of technology for the construction of defensive objects for this region ("opus quadratum" masonry, bed stepped masonry of processed blocks, fan masonry) and local construction techniques (masonry of undressed blocks of different configurations, base of small pebbles to form their stable position, etc.) were used.

Of particular importance are complex technological techniques for connection of massive military engineering facilities that ensure the strength of the defensive structure as a whole, its resistance to natural phenomena (the location in the zone of increased tectonic activity), as well as to the assault techniques of the early Middle Ages [13, p. 14-15; 14, p. 167; 15, p. 95-96].

\section{Acknowledgements}

1. The paper presents materials of excavations collected with the financial support of the RFBR and the Government of the Republic of Dagestan (project of 2012-2014: "Landscapes of the Western Caspian region in the cultural genesis of ethnic communities in the era of the Great Peoples' Migration"), RFBR (project of 2016-2018: "International Strategic Defense System in the Eastern Caucasus during the era of the Great Peoples' Migration"), Head of the Republic of Dagestan V.A. Vasilyev (project of 2020: "A new monumental defensive structure on the Rubas river in South Dagestan (6th century): study and problems of interpretation").

2. The illustrative material was prepared with the help of V.A. Saidov and Yu.A. Magomedov.

3. Aerial photography of 2020 of the Rubas defensive complex was carried out by by B.H. Gadzhiev.

4. The drawing documentation of the objects of the Rubas fortification was made by Z.Z. Kuzeeva.

5. The full profile of the eastern facade of Wall 3 is made by L.B. Gmyrya and Yu. A. Magomedov. 


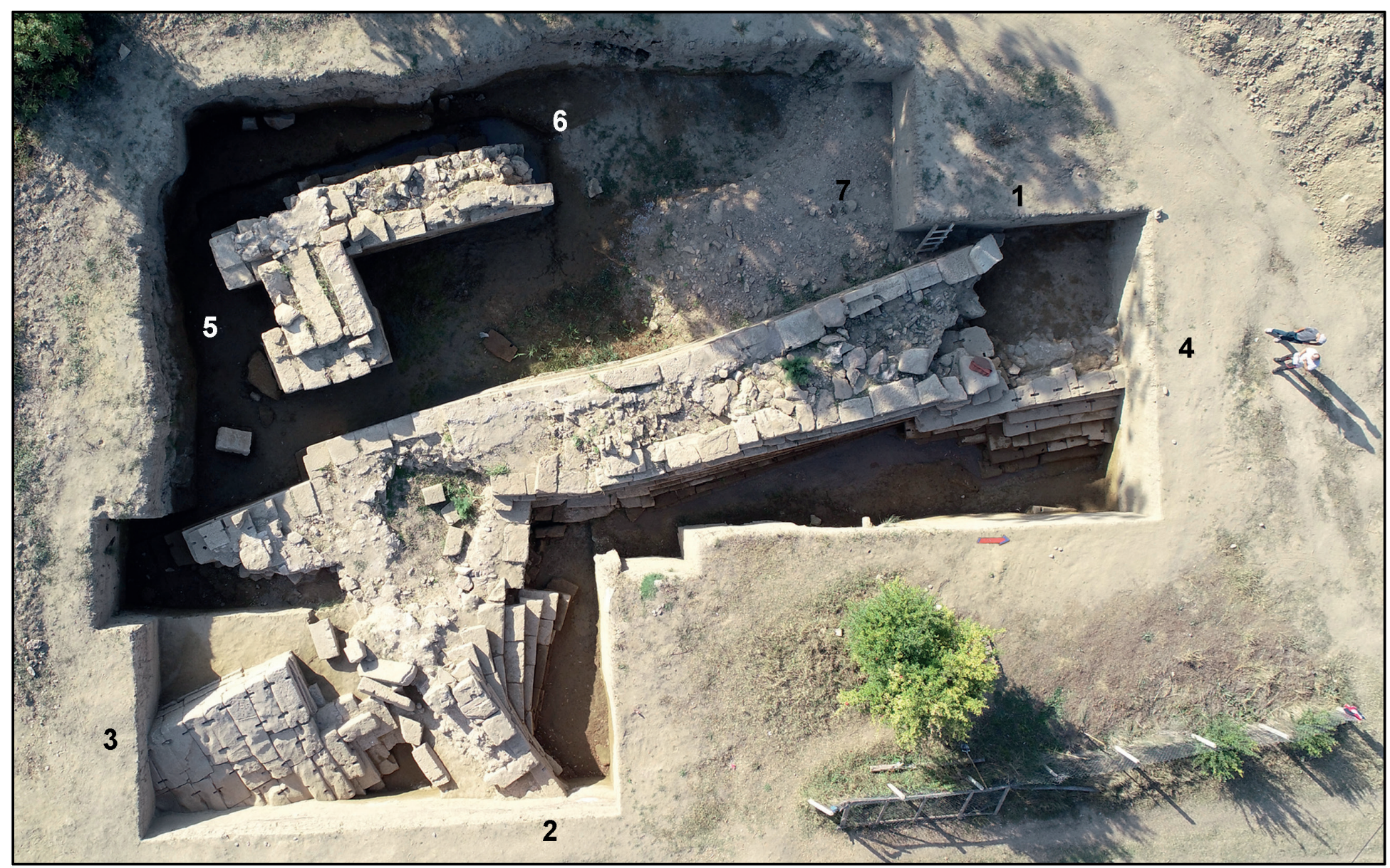

Fig. 1. Monumental structure on Rubas.

1-Wall 2; 2 - Wall 3; 3 - Structure 5 (platform); 4 - Structure 6 (annex); 5 - arched structure; 6 - Wall 1; 7 mudflowsediments. View from east. Air-drone photo of 2020. Previously unpublished

Рис. 1. Монументальное архитектурное сооружение на р. Рубас.

1 -стена №2; 2 - стена №3; 3 - сооружение №5 (платформа);

4 - сооружение №6 (пристройка); 5 - сооружение арочной конструкции; 6 - стена №1; 7 - отложения селя. Вид с востока. Аэрофотосъемка беспилотным летательным аппаратом 2020 г. Публикуется впервые 


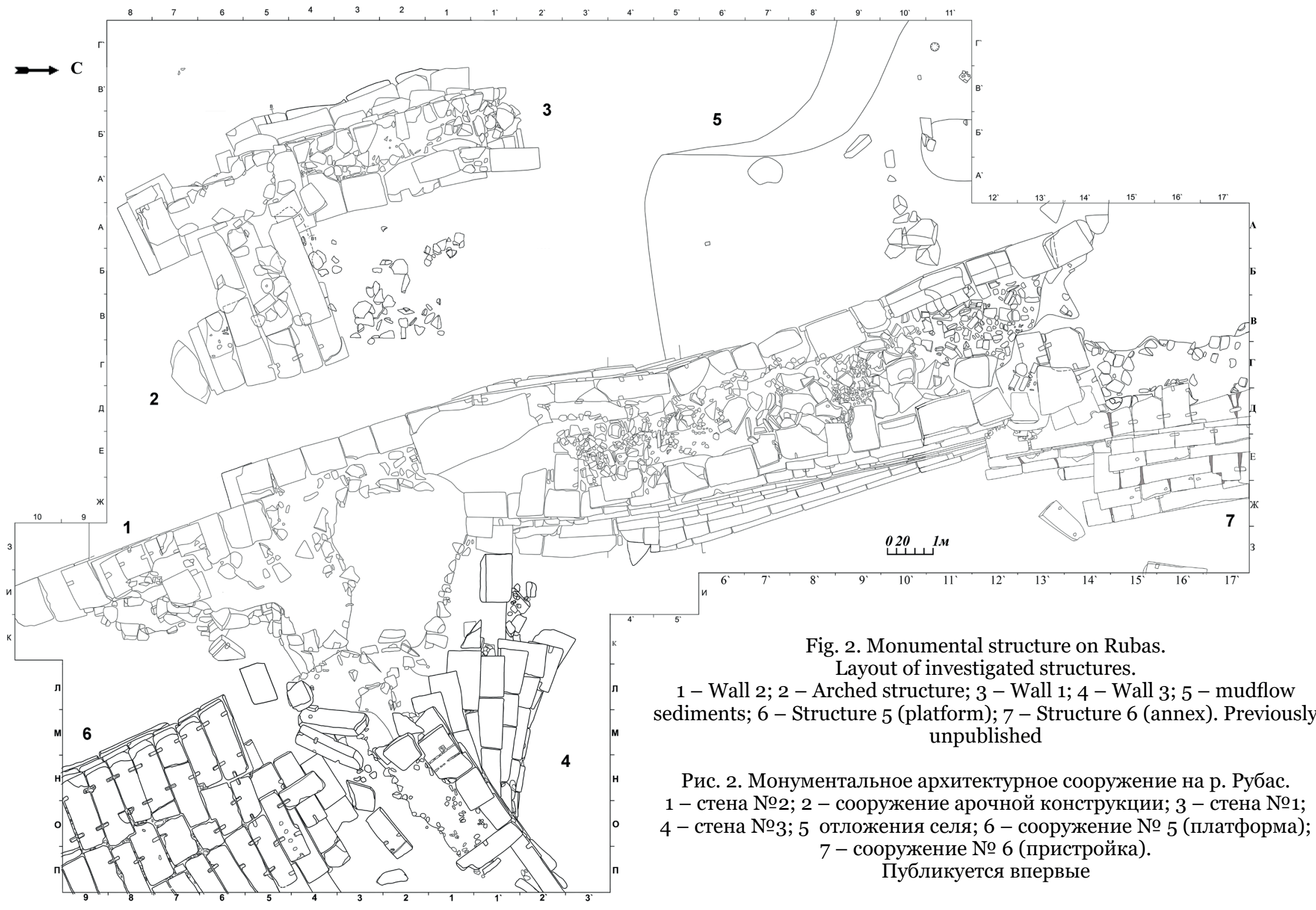




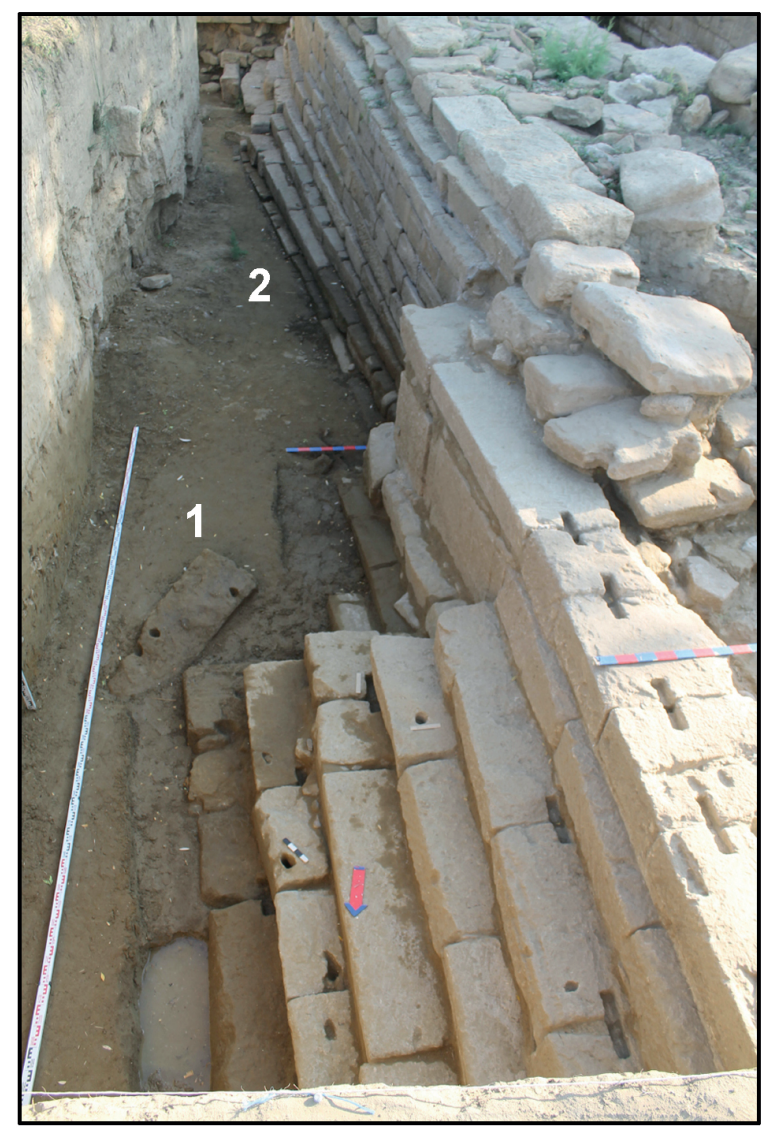

Fig. 3. Monumental structure on Rubas. 1 - Structure 6 (annex);

2 - Wall 2. View from north. Photo of 2020. Previously unpublished

Рис. 3. Монументальное архитектурное сооружение на р. Рубас.

1 - сооружение №6 (пристройка) 2 - стена №2. Вид с севера. Фото 2020 г. Публикуется впервые

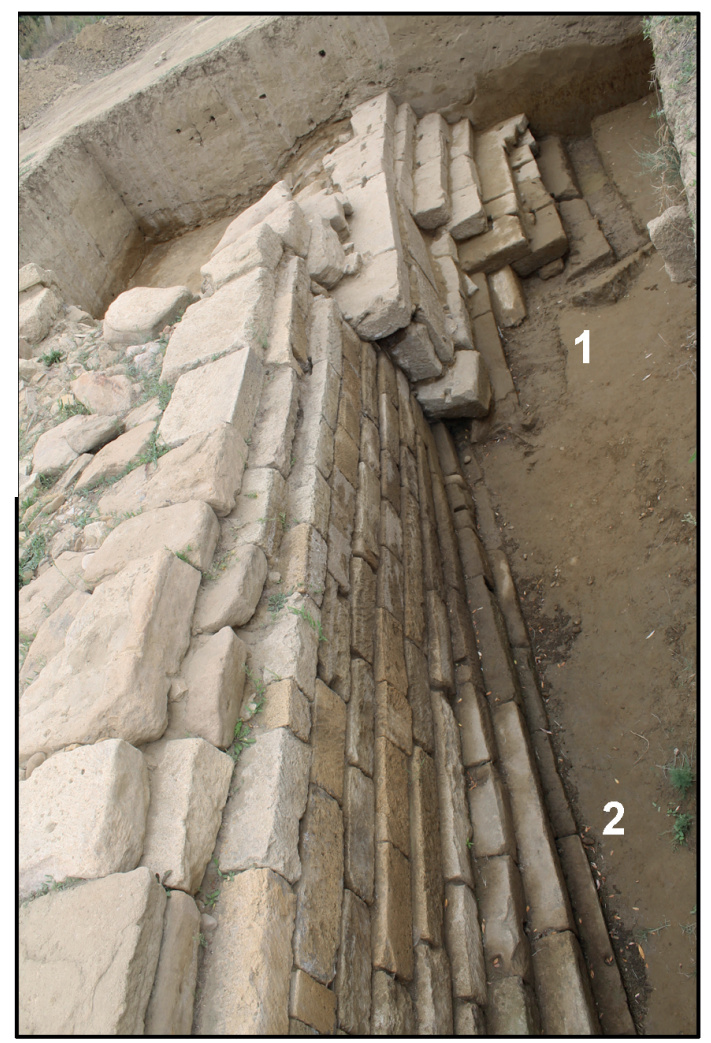

Fig. 4. Monumental structure on Rubas. 1 - Structure 6 (annex); 2 - Wall 2. View from south. Photo of 2020. Previously unpublished

Рис. 4. Монументальное архитектурное сооружение на р. Рубас. 1 -сооружение № 6 (пристройка); 2 - стена № 2. Вид с юга. Фото 2020 г. Публикуется впервые 


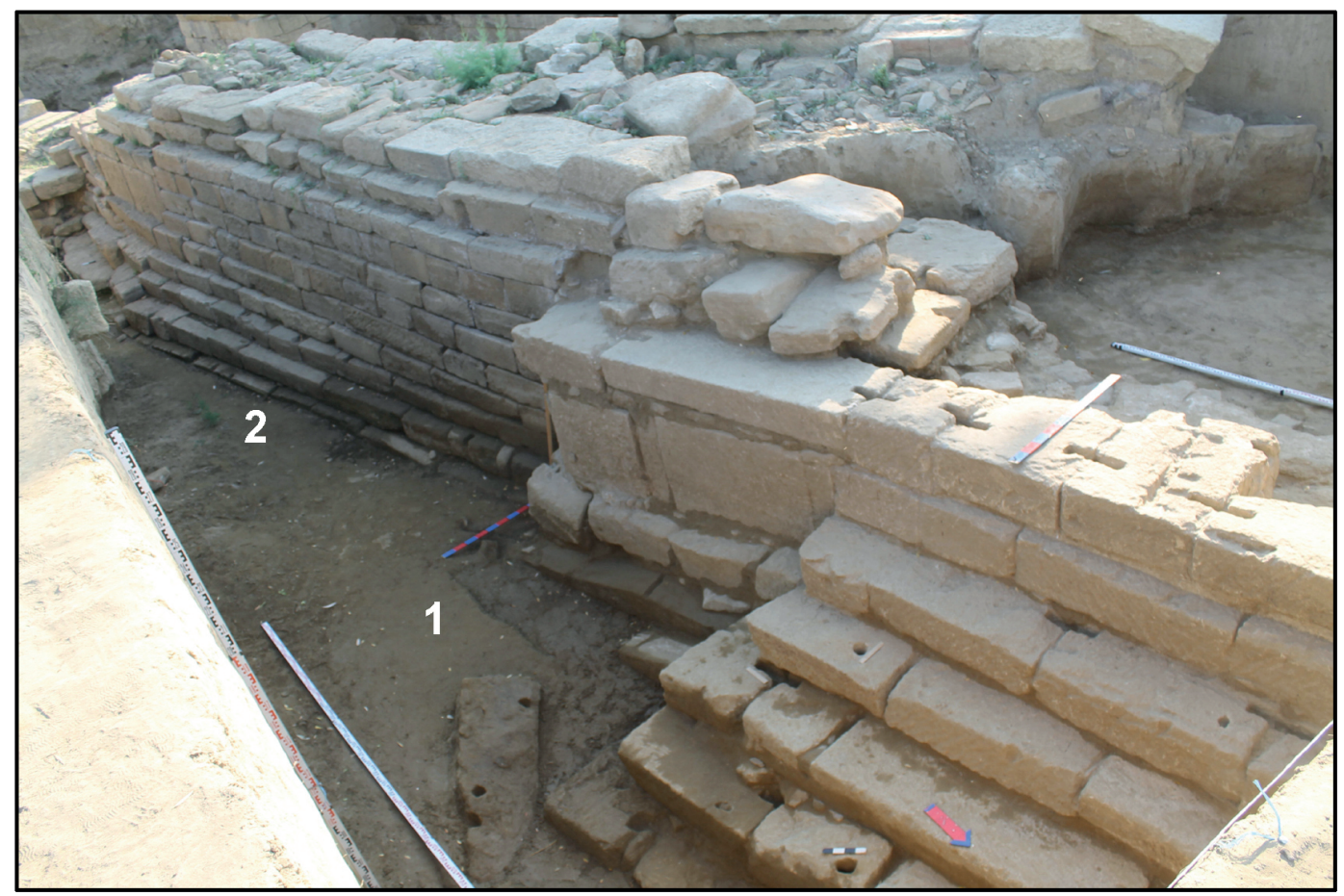

Fig. 5.Monumental structure on Rubas. 1 - Structure 6 (annex); 2 - Wall 2. View from north-east. Photo of 2020. Previously unpublished

Рис. 5. Монументальное архитектурное сооружение на р. Рубас. 1 - сооружение № 6 (пристройка); 2 - стена № 2. Вид с северо-востока. Фото 2020 г. Публикуется впервые

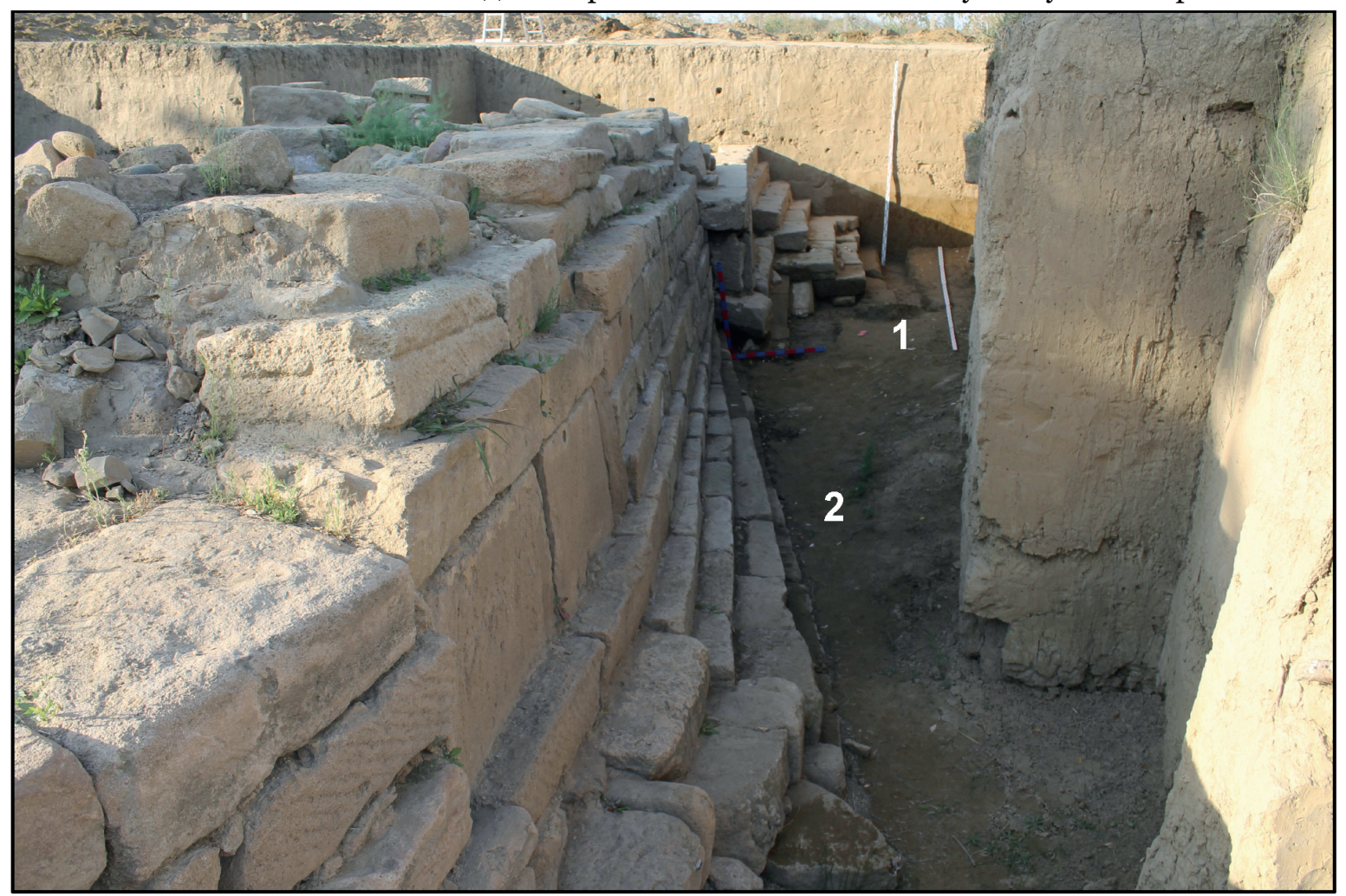

Fig. 6. Monumental structure on Rubas. 1 - Structure 6 (annex); 2 - Wall 2. View from south. Photo of 2020. Previously unpublished

Рис. 6. Монументальное архитектурное сооружение на р. Рубас.

1 - сооружение № 6 (пристройка); 2 - стена № 2. Вид с юга. Фото 2020 г. Публикуется впервые 


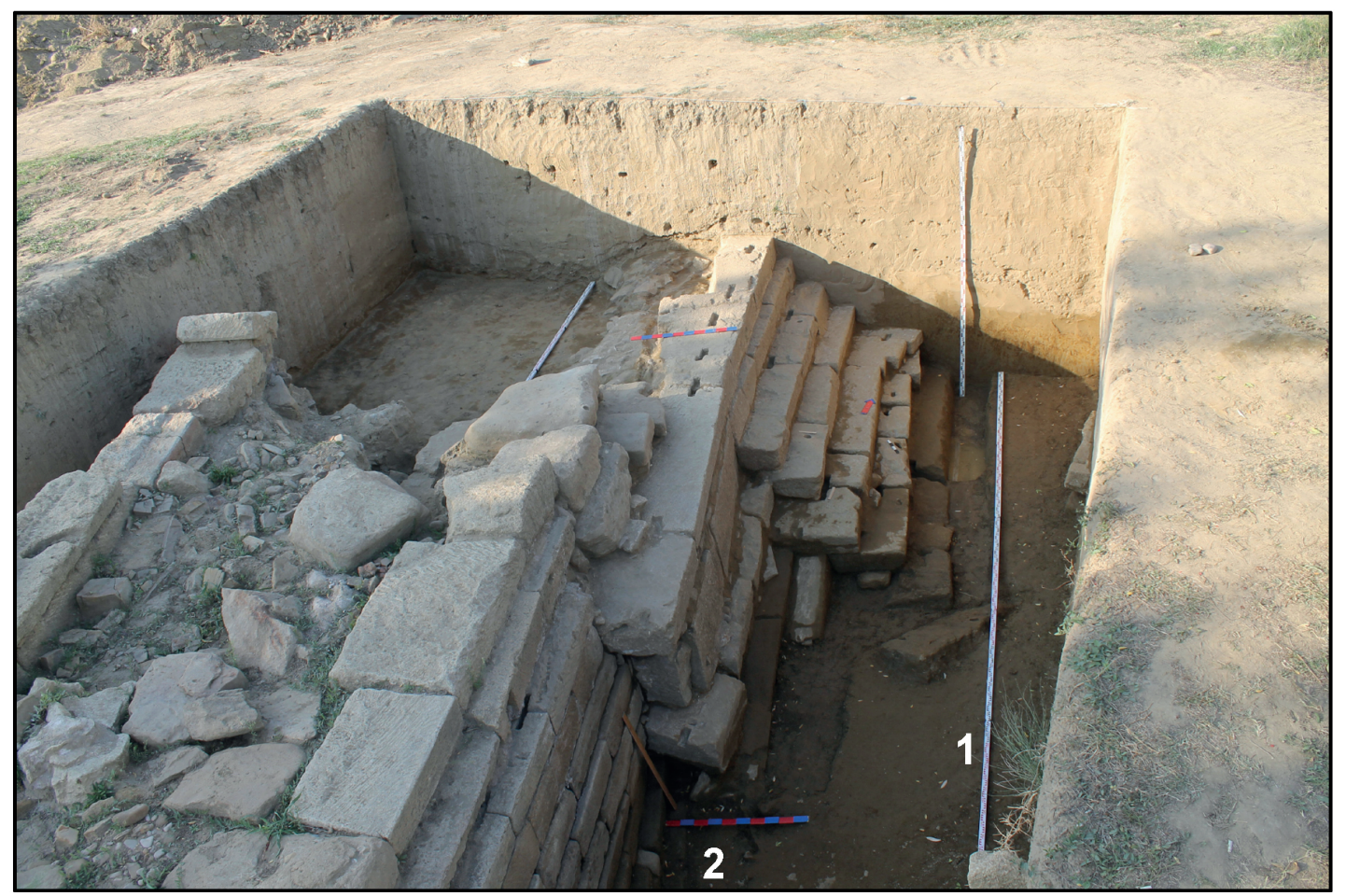

Fig. 7. Monumental structure on Rubas. 1 - Structure 6 (annex); 2 - Wall 2. View from south. Photo of 2020. Previously unpublished

Рис. 7. Монументальное архитектурное сооружение на р. Рубас. 1 - сооружение №6 (пристройка); 2 - стена № 2. Вид с юга. Фото 2020 г. Публикуется впервые

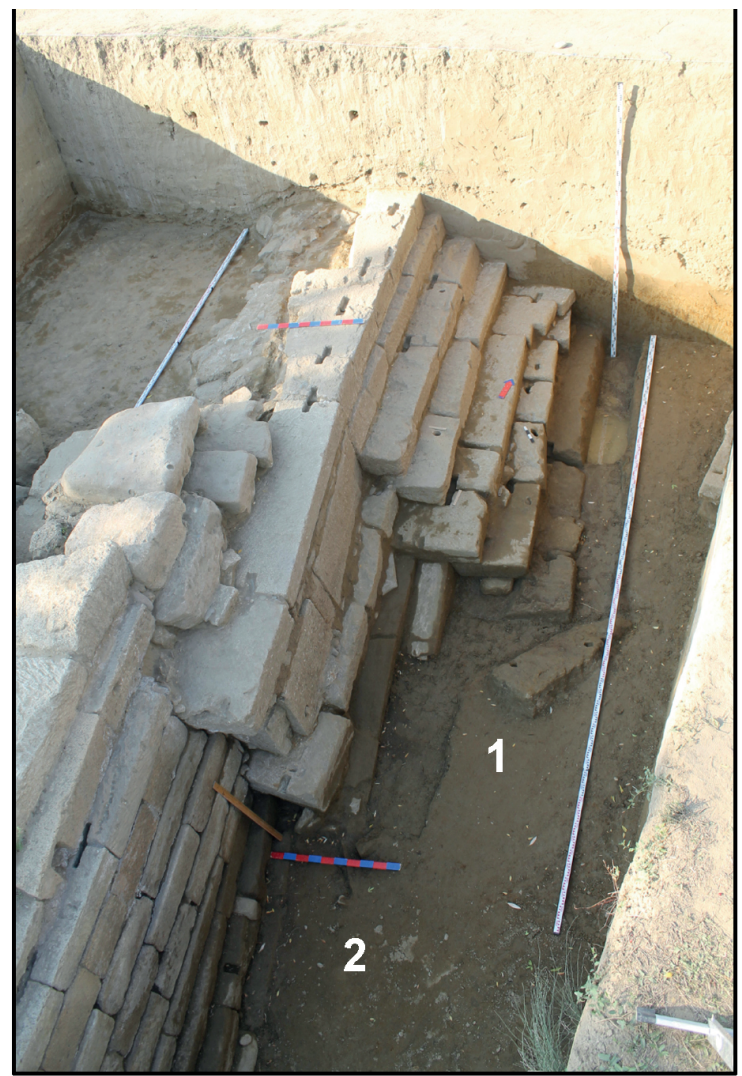

Fig. 8. Monumental structure on Rubas. 1 - Structure 6 (annex); 2 - Wall 2. View from south. Photo of 2020. Previously unpublished

Рис. 8. Монументальное архитектурное сооружение на р. Рубас. 1 - сооружение № 6 (пристройка); 2 - стена №2. Вид с юга. Фото 2020 г. Публикуется впервые 


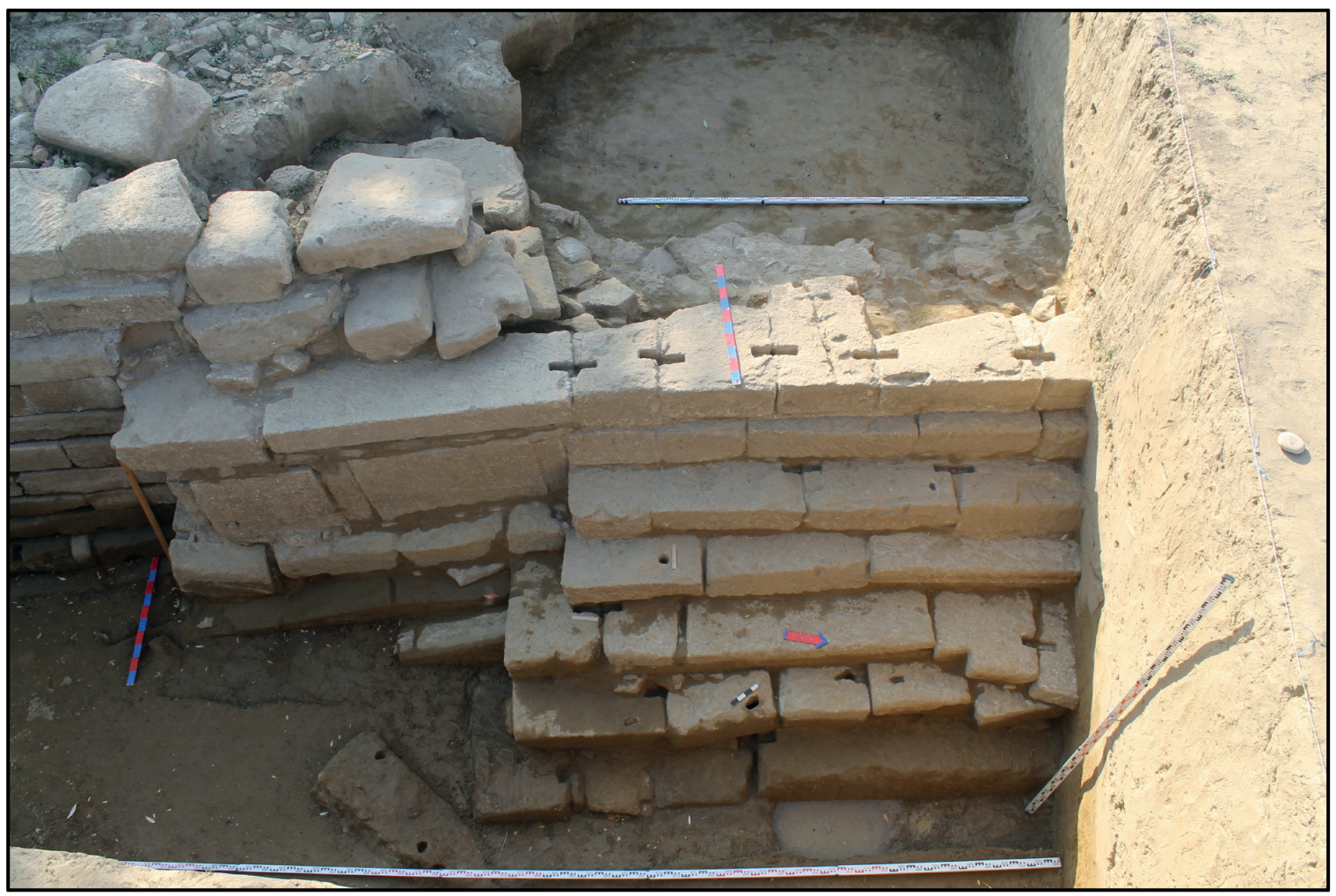

Fig. 9. Monumental structure on Rubas. Structure 6 (annex). View from east. Photo of 2020

Рис.9. Монументальное архитектурное сооружение на р. Рубас. Сооружение № 6 (пристройка). Вид с востока. Фото 2020 г.

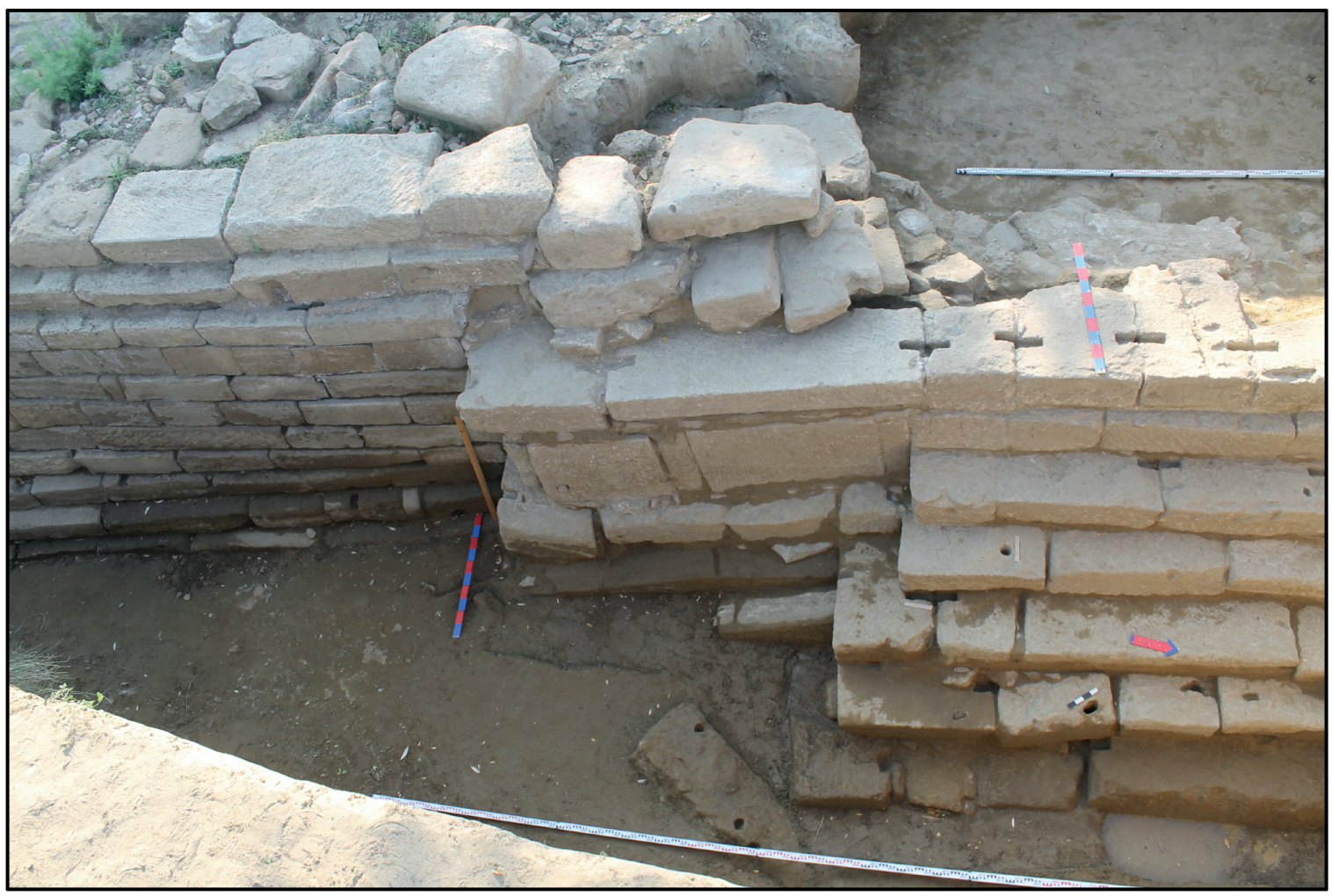

Fig. 10. Monumental structure on Rubas. Structure 6 (annex). View from north-east. Photo of 2020. Previously unpublished

Рис.10. Монументальное архитектурное сооружение на р. Рубас. Сооружение № 6 (пристройка). Вид с северо-востока. Фото 2020 г. Публикуется впервые 


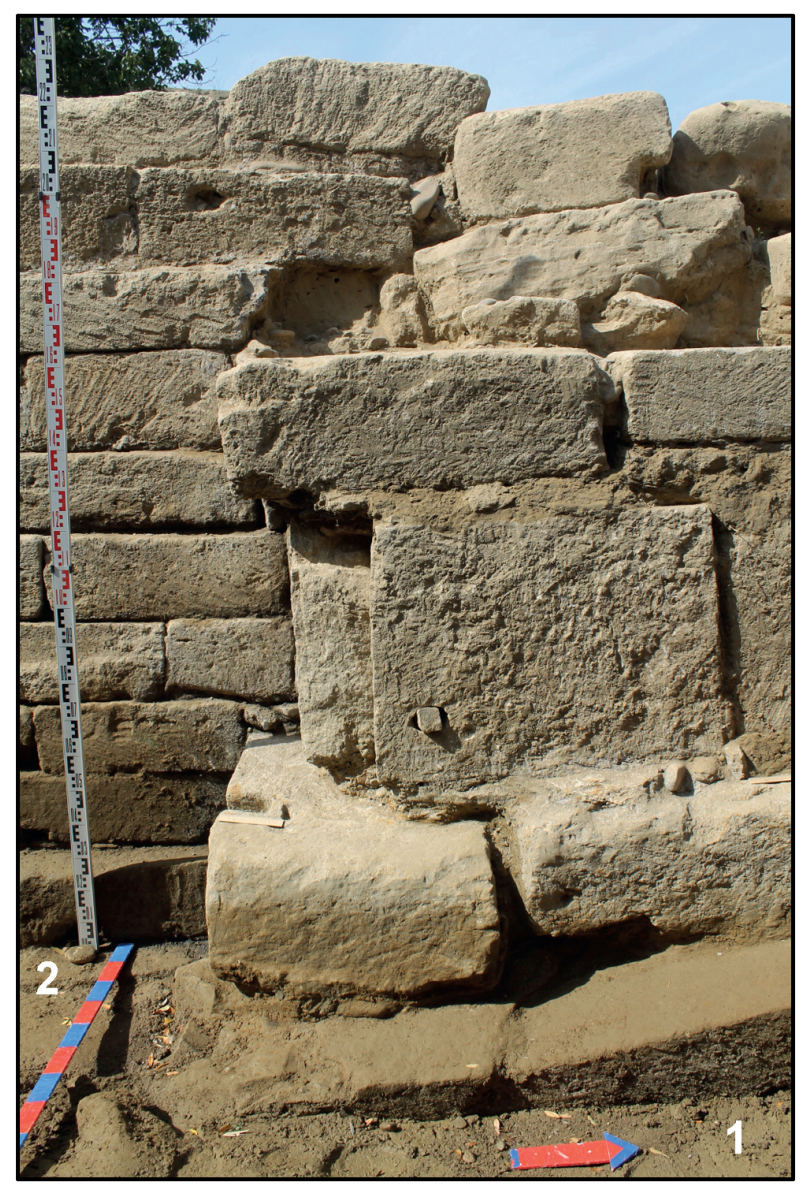

A

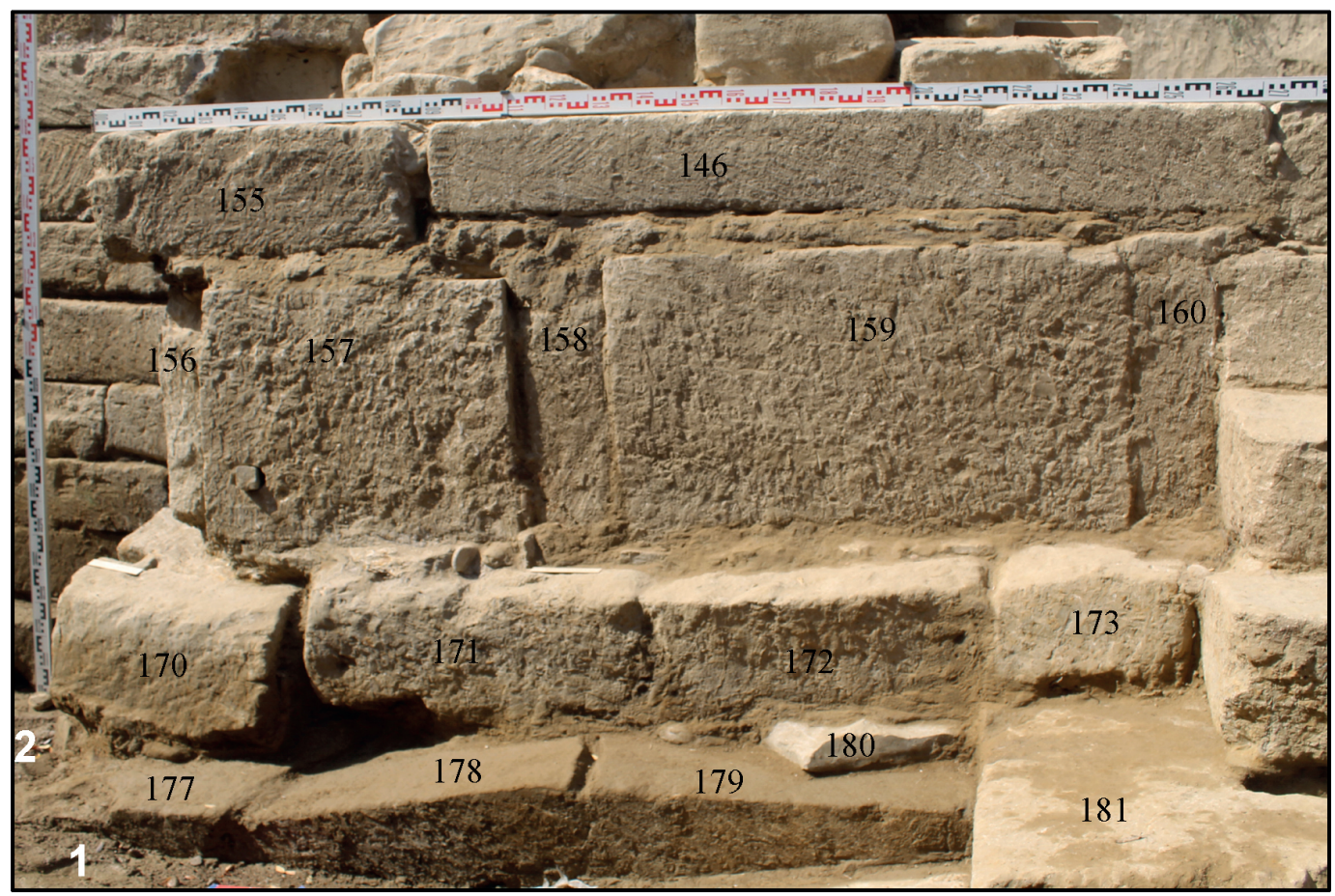

Fig. 11. Monumental structure on Rubas. A-B. 1 - Structure 6 (southern section); 2 - Wall 2 (northern section). View from east. Photo of 2020. Previously unpublished

Рис.11. Монументальное архитектурное сооружение на р. Рубас.

А-Б. 1 - сооружение № 6 (южный участок). 2 - стена № 2 (северный участок). Вид с востока. Фото 2020 г. Публикуется впервые 


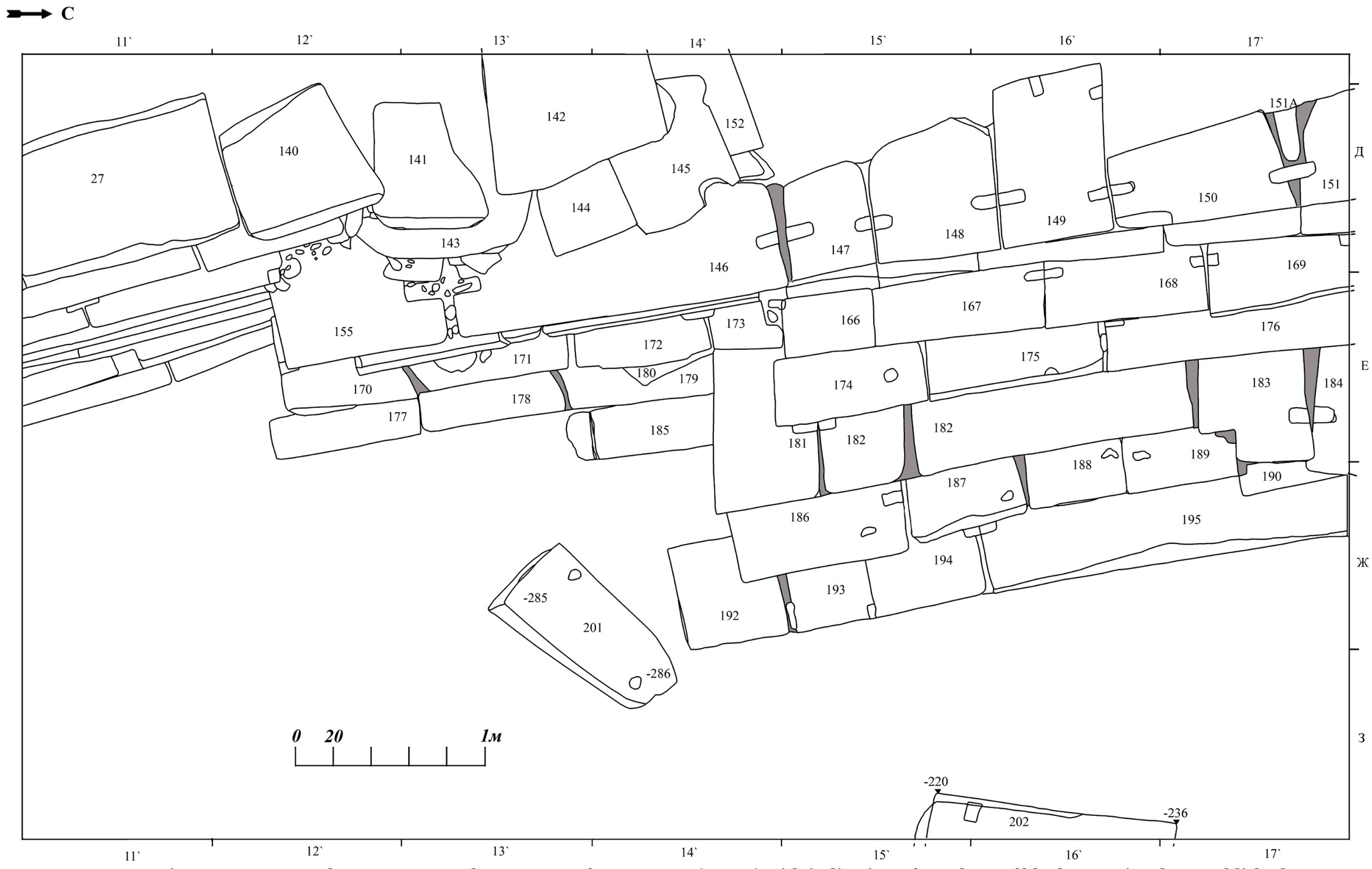

Fig. 12. Monumental structure on Rubas. Layout of Structure 6 (annex) with indication of numbers of blocks. Previously unpublished

Рис.12. Монументальное архитектурное сооружение на р. Рубас. План сооружения №6 (пристройка) с указанием №№ блоков. Публикуется впервые 


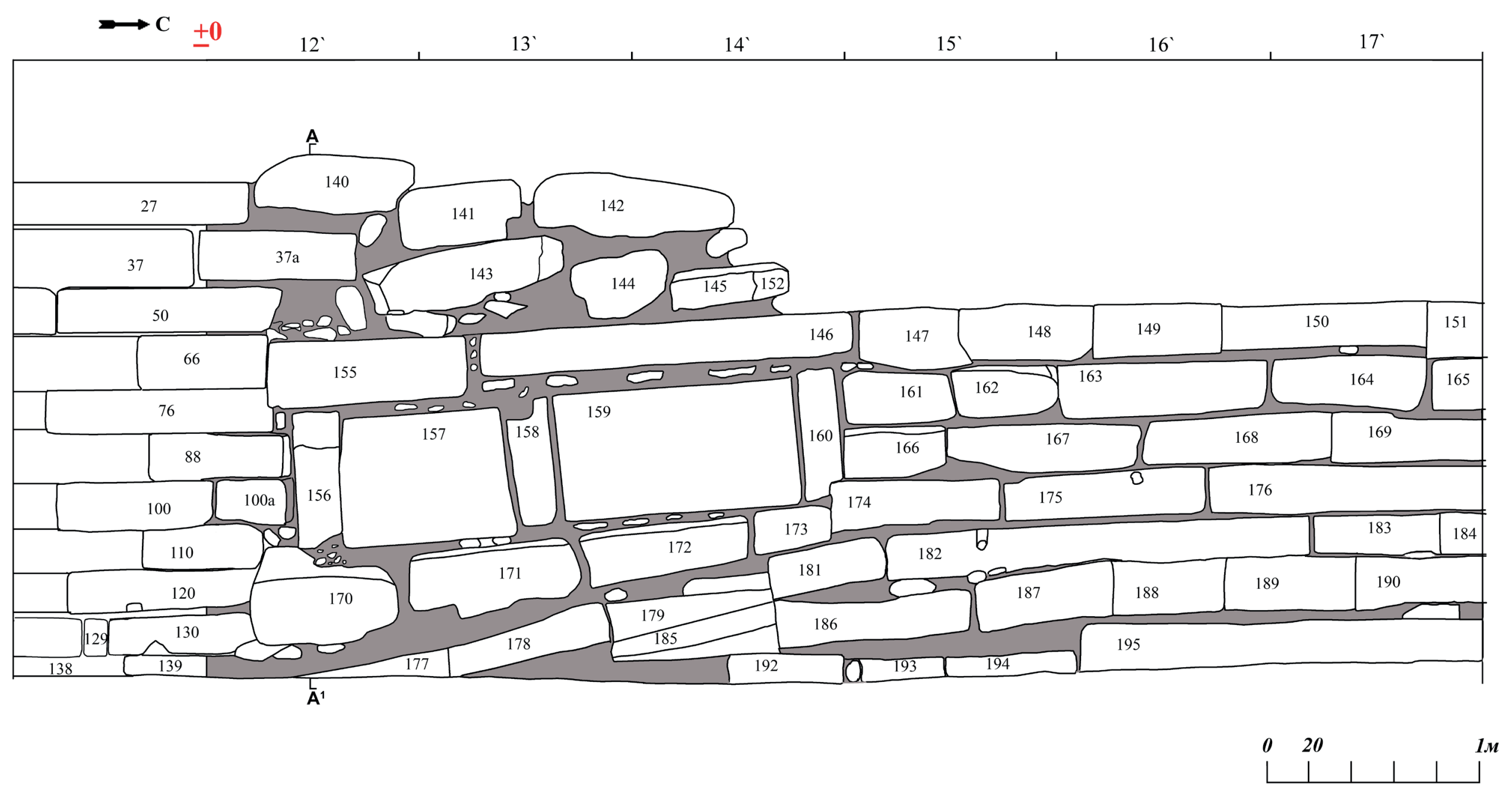

Fig. 13. Monumental structure on Rubas. Structure 6 (annex). East face with indication of numbers of blocks. Previously unpublished

Рис. 13. Монументальное архитектурное сооружение на р. Рубас. Сооружение № 6 (пристройка). Восточный фас с указанием №№ блоков. Публикуется впервые 


$$
\pm 0
$$
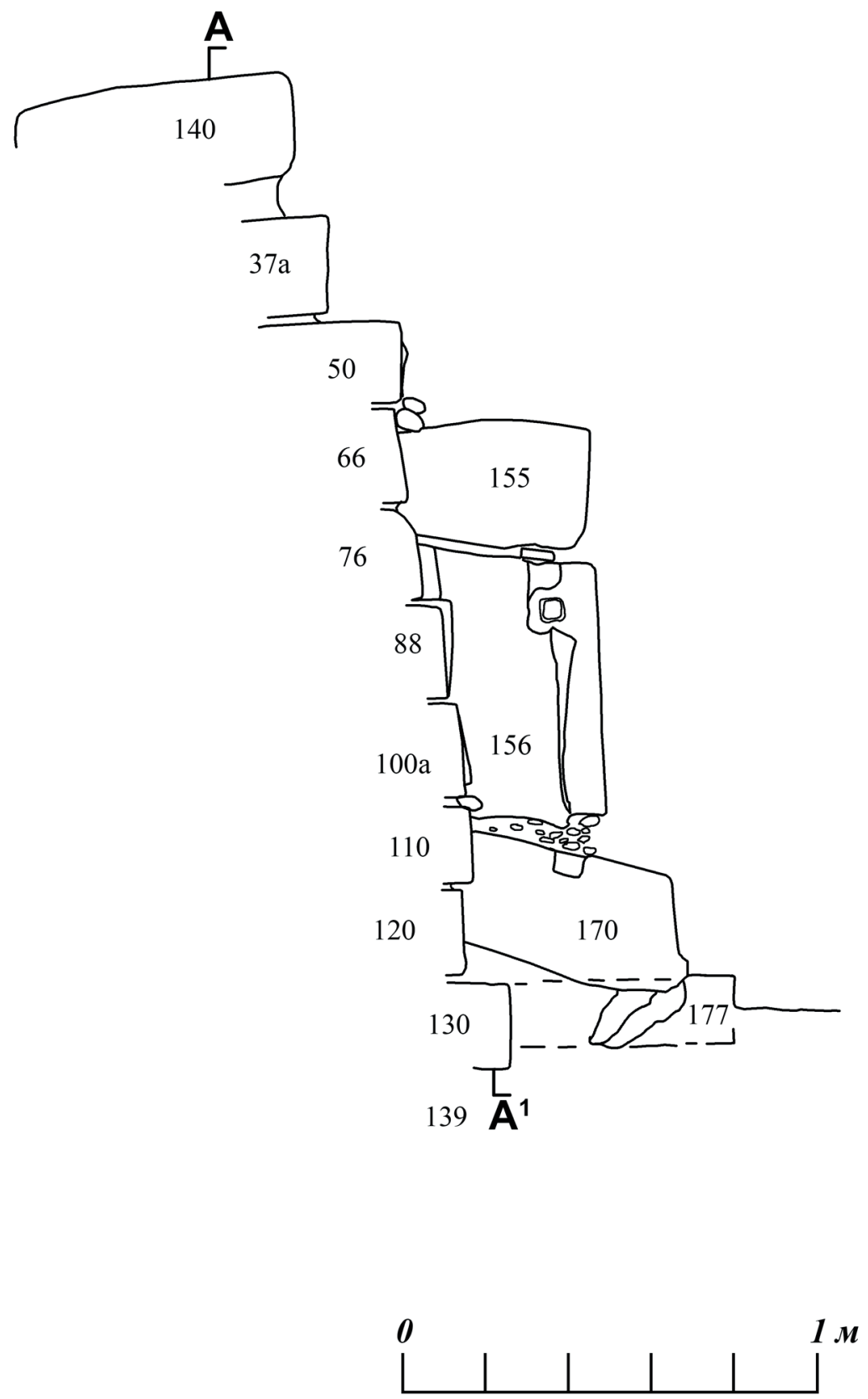

Fig. 14. Monumental structure on Rubas. Structure 6 (annex). Cross section on A-1 line. Previously unpublished

Рис. 14. Монументальное архитектурное сооружение на р. Рубас. Сооружение № 6 (пристройка). Разрез по линии А-А1.

Публикуется впервые 


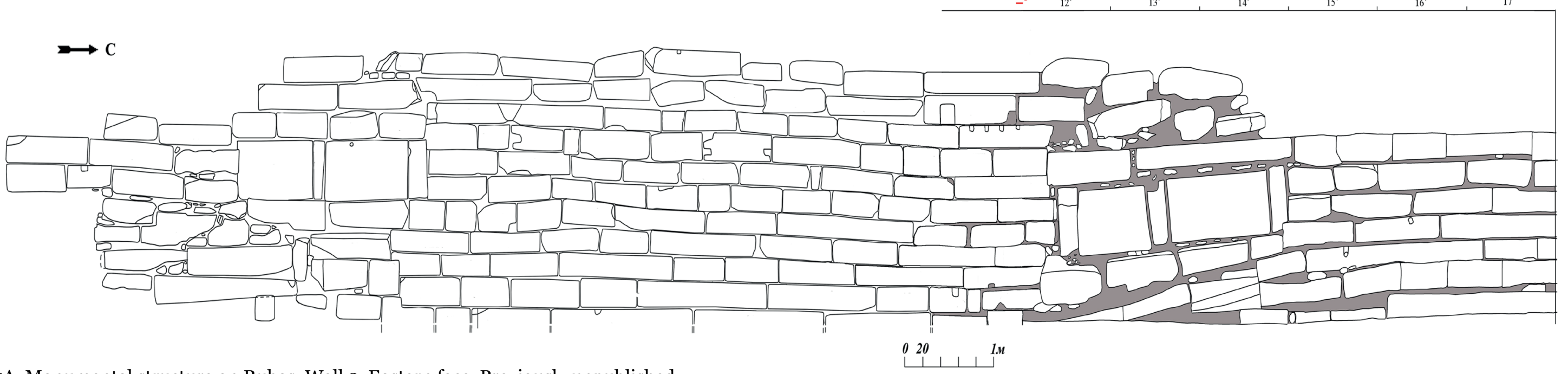

Fig. 15A. Monumental structure on Rubas. Wall 2. Eastern face. Previously unpublished

Рис. 15А. Монументальное архитектурное сооружение на р. Рубас.

Сооружение № 2. Восточный фас. Публикуется впервые

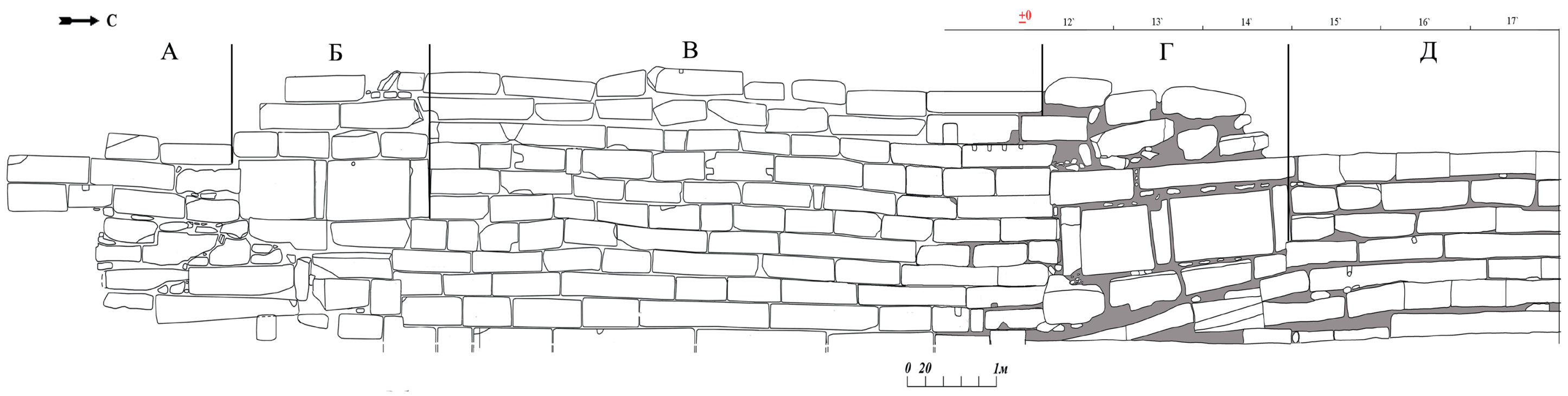

Fig. 15B. Monumental structure on Rubas. A, B, C, D, E - architectural sections. Previously unpublished.

Рис. 15Б. Монументальное архитектурное сооружение на р. Рубас. Сооружение № 2. Восточный фас. А,Б,В,Г,Д - архитектурные участки. Публикуется впервые 


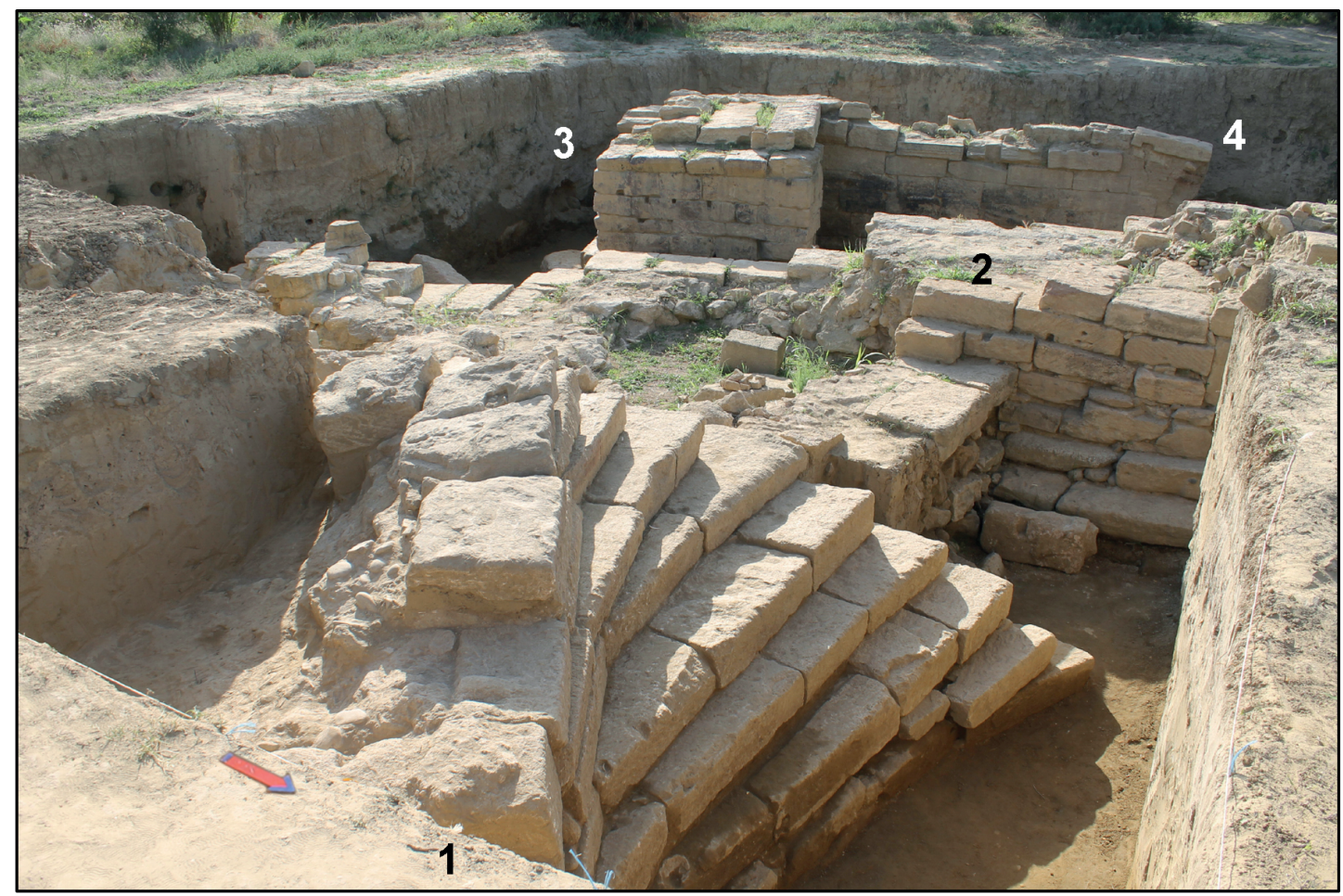

Fig. 16. Monumental structure on Rubas. 1 - Wall 3; 2 - Wall 2; 3 - arched structure; 4 - Wall 1. View from east. Photo of 2020. Previously unpublished.

Рис. 16. Монументальное архитектурное сооружение на р. Рубас. 1 - стена №3; 2 - стена № 2; 3 - сооружение арочной конструкции; 4 - стена №1. Вид с востока. Фото 2020 г. Публикуется впервые

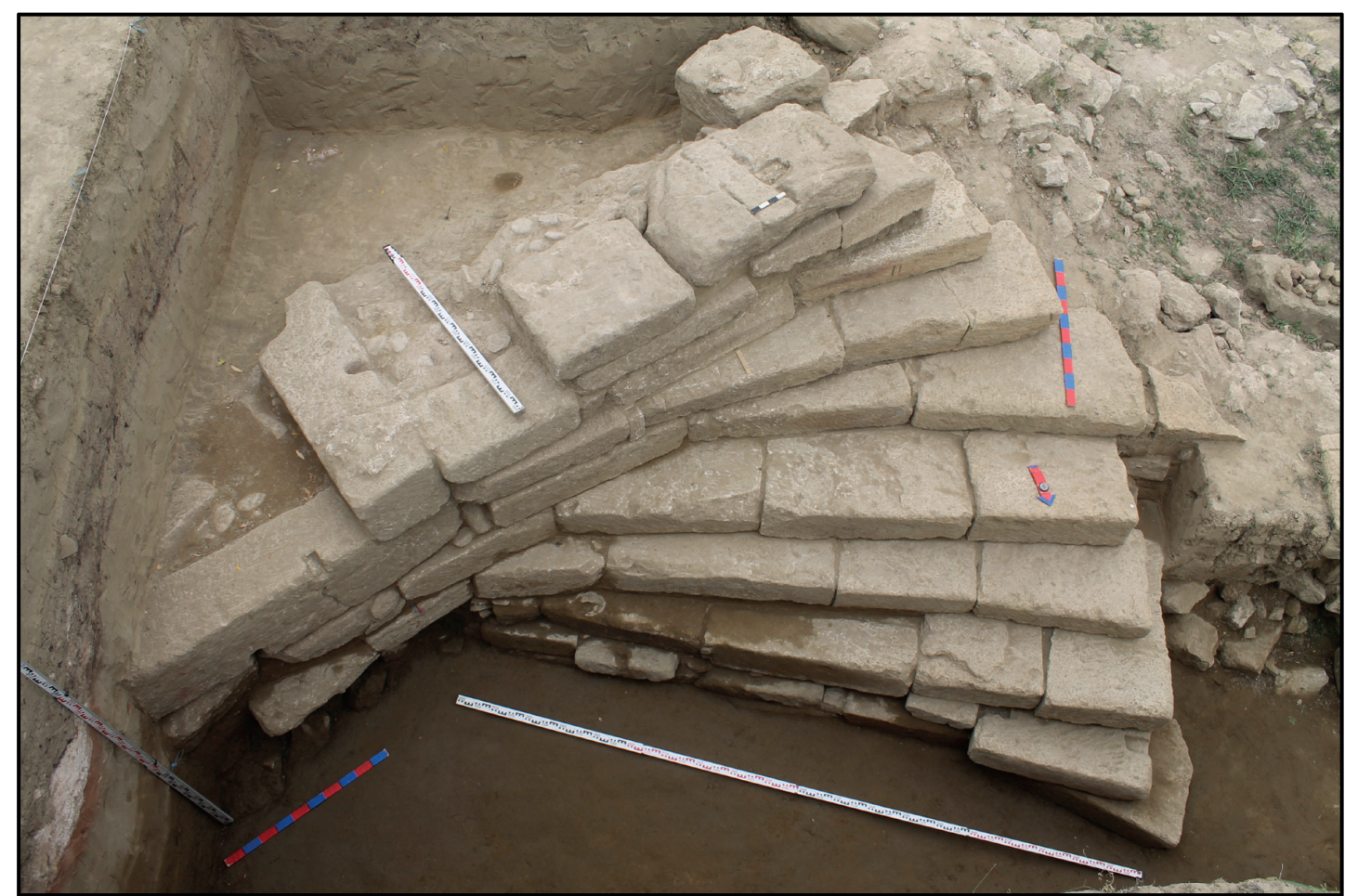

Fig. 17. Monumental structure on Rubas. Wall 3. View from north. Photo of 2020. Previously unpublished

Рис. 17. Монументальное архитектурное сооружение на р. Рубас. Стена № 3. Вид с севера. Фото 2020 г. Публикуется впервые 


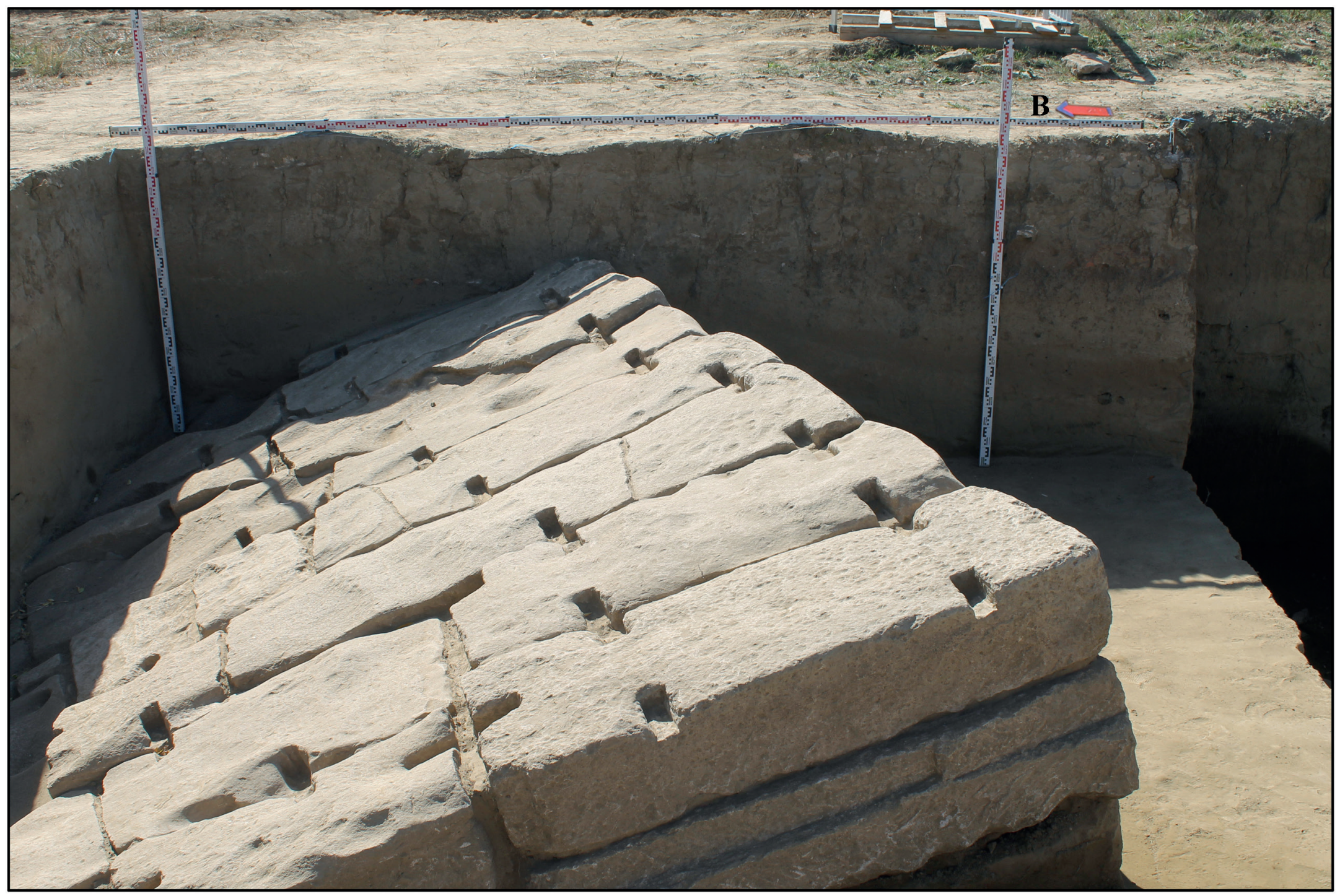

Fig. 18. Monumental structure on Rubas. Structure 5 (platform). View from north. Previously unpublished

Рис. 18. Монументальное архитектурное сооружение на р. Рубас. Сооружение №5 (платформа). Вид с севера. Фото 2020 г. Публикуется впервые 


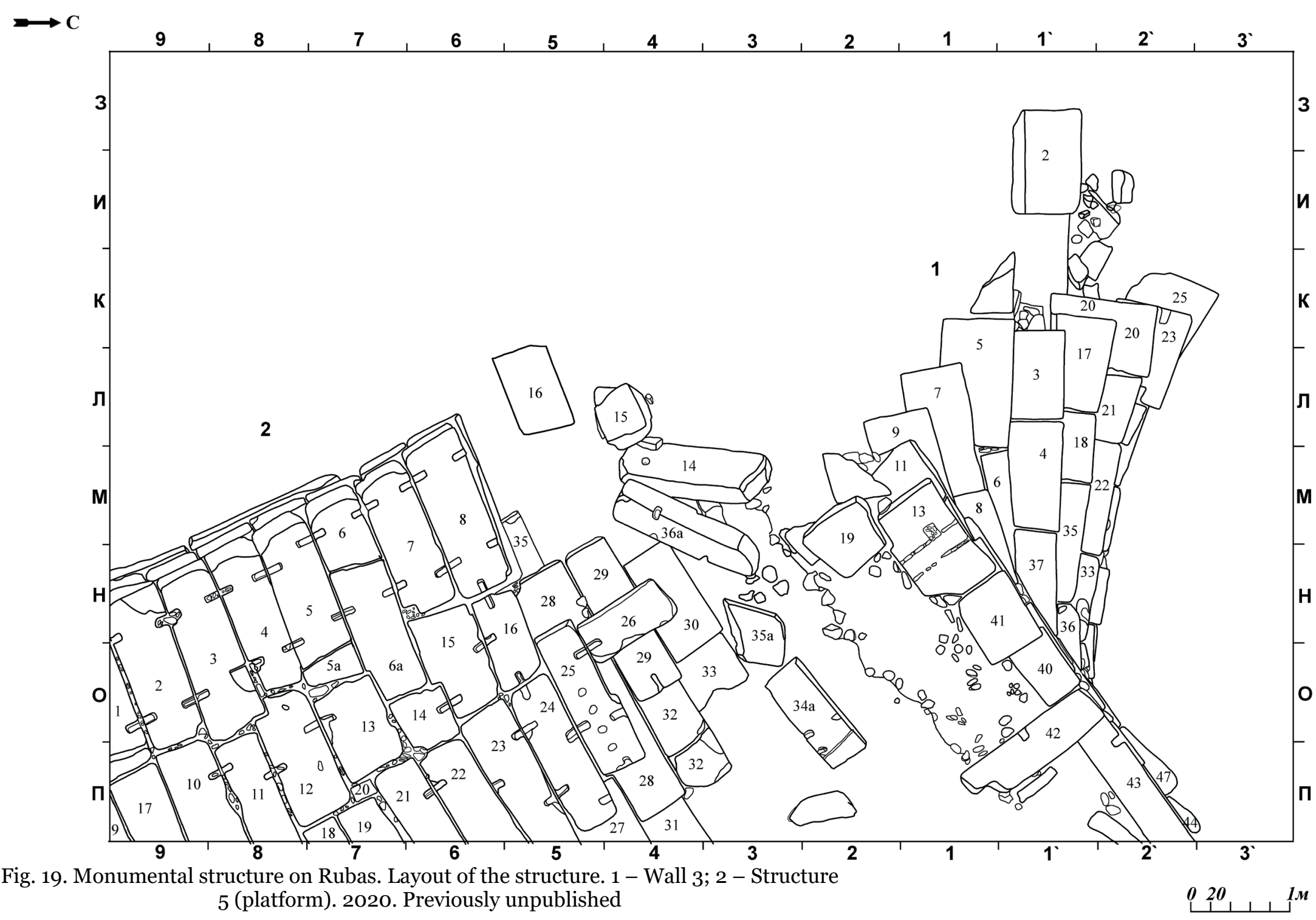

Рис. 19. Монументальное архитектурное сооружение на р. Рубас. План сооружений. 1 - стена №3; 2 - сооружение №5 (платформа). 2020 г. Публикуется впервые 


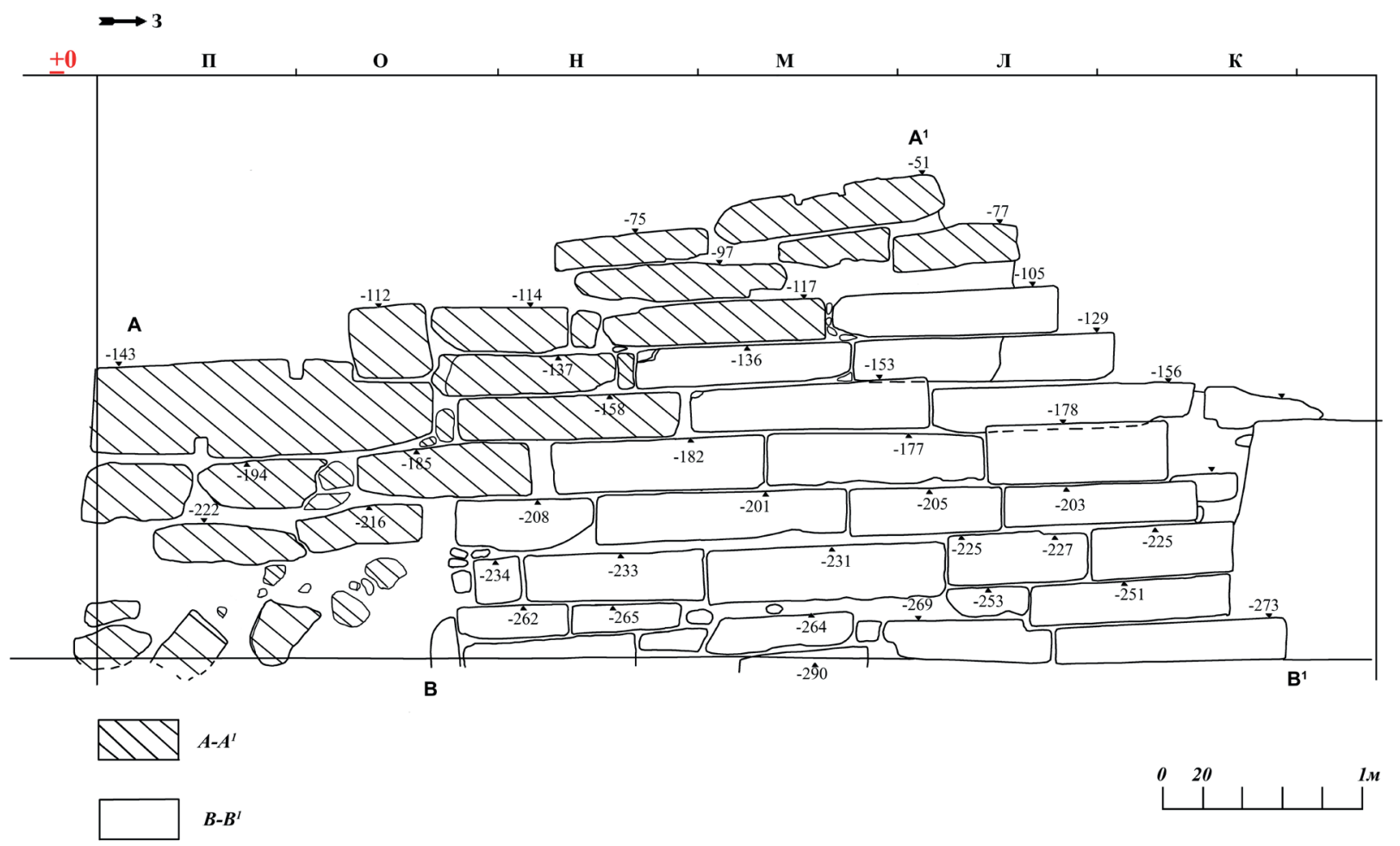

Fig. 20. Monumental structure on Rubas. Wall 3. North face with indication of levelling marks of blocks. 2020. Previously unpublished

Рис. 20. Монументальное архитектурное сооружение на р. Рубас. Стена № 3. Северный фас с указанием нивелировочных отметок блоков. 2020 г. Публикуется впервые

C
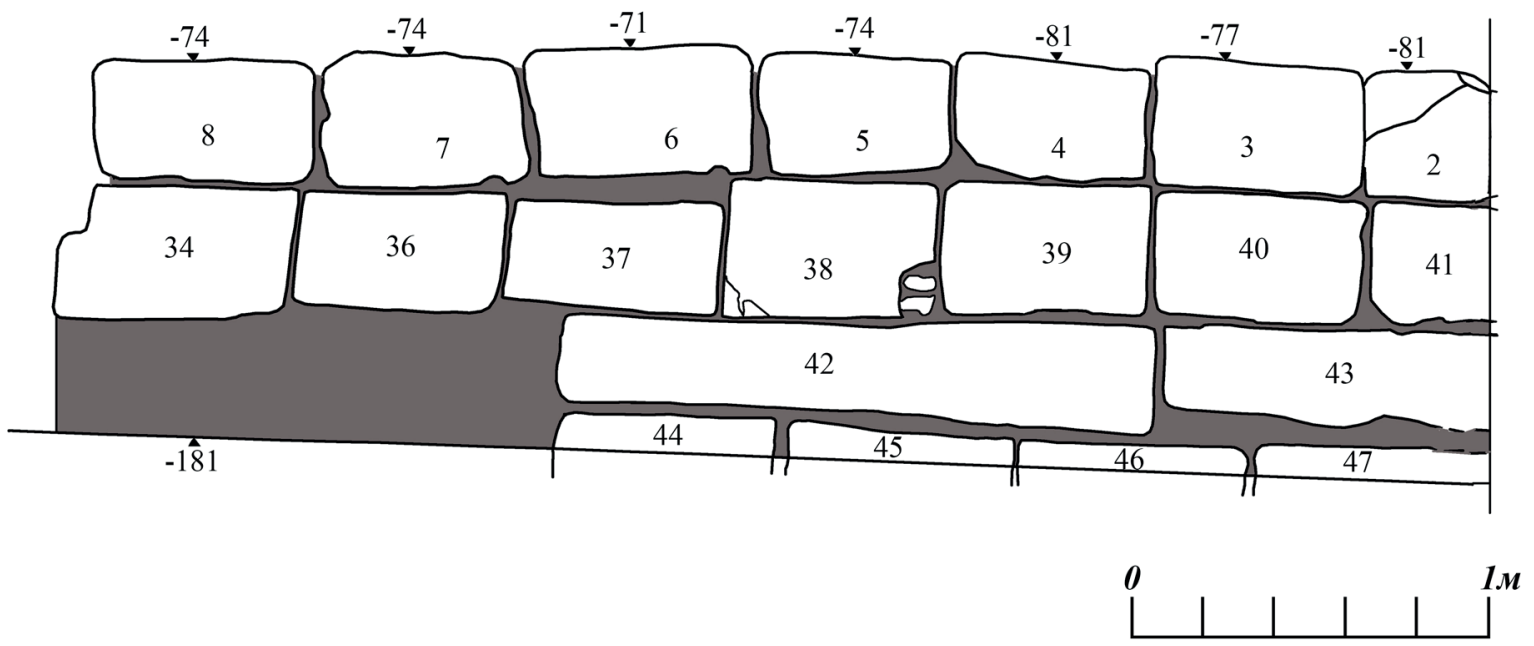

Fig. 21. Monumental structure on Rubas.

Structure 5 (platform). Western face with indication of levelling marksand numbers of blocks. Previously unpublished

Рис. 21. Монументальное архитектурное сооружение на р. Рубас. Сооружения № 5 (платформа). Западный фас с указанием нивелировочных отметок и №№ блоков. Публикуется впервые 


\section{REFERENCES}

1. Gmyrya LB, Saidov VA, Magomedov YuA. Study of the Rubas fortification in 2018. History, archeology and ethnography of the Caucasus. 2019, 15(1): 62-86. (In Russ)

2. Gmyrya LB, Saidov VA, Magomedov YuA. Study of the Rubas fortification in 2020.History, archeology and ethnography of the Caucasus. 2020, 16(4): 1099-1139. (In Russ)

3. Gmyrya LB. Specifics of the Rubas fortification's topography and layout (East Caucasus). Izvestiya SOIGSI. 2019, 34(73): 5-25. (In Russ)

4. Gmyrya LB, Shikhaliev Sh.Sh., Shekhmagomedov M.G., Kuzeeva Z.Z. Ceramic jug with an imprint of the text of the ayat Surah Koran from Southern Dagestan (XII century). Herald of the Dagestan Scientific Center. 2015, 56: 28-35. (In Russ)

5. Gmyrya LB, Korzhenkov A.M., Ovsyuchenko A.N., Larkov A.S., Rogozhin E.A. Probable field seismic deformations at the Rubas archaeological site of the middle of the 6th century. Southern Dagestan. Geophysical Processes and Biosphere. 2019, 18(3): 91-103.

6. Gmyrya LB, Korzhenkov A.M., Ovsyuchenko A.N., Larkov A.S., Rogozhin E.A. Probable Paleoseismic Deformations at the Rubas Archeological Site, Mid-6th Century AD, South Dagestan. ISSN 0oo1-4338, Izyestiya, Atmospheric and Oceanic Physics. 2019, 55(10): 1547-1558. (C) Pleiades Publishing, Ltd., 2019. Russian Text (C) The Author (s), 2019, published in Geofizicheckie Protsessy I Biosfera, 2019, 18(3): 91-103.

7. Pakhomov E.A. The largest monuments of Sassanian construction in the Transcaucasus. Problems of the history of material culture. 1933, 9-10: 39-46. (In Russ)

8. Trever K.V. Essays on the history and culture of Caucasian Albania. IV century BC - VII century $A D$. Moscow; Leningrad, 1959. (In Russ)

9. Aliev A.A., Aliev I.N., Gadjiev M.S., Geithner M.G., Kohl F.L., Magomedov R.G. New studies of the Gilgilchay defensive wall. Problems of history, philology and culture. 2004, 14: 441-465. (In Russ)

10. Gadjiev M.S., Kudryavcev A.A. Steinmetzzeichen des 6. Jahrhundert in Darband. Archäologische Mitteilungeaus Iran und Turan. Hrsg. vom Deutschen Archäologischen Institut Eurasien-Abteilung, A u Benstelle. Teheran. Bd. 33. Berlin: Reimer, 2001:357-390.

\section{СПИСОК ЛИТЕРАТУРЫ}

1. Гмыря Л.Б., Саидов В.А., Магомедов Ю.А. Исследование Рубасской фортификации в 2018 г. // История, археология и этнография Кавказа. Т. 15. № 1. 2019. С. 62-86.

2. Гмыря Л.Б., Саидов В.А., Магомедов Ю.А. Исследование Рубасской фортификации в 2020 г. // История, археология и этнография Кавказа. Т. 16. № 4. 2020. С. 10991139.

3. Gmyrya L.B. Specifics of the Rubas fortification's topography and layout (Eastern Caucasus) // Известия СОИГСИ. 2019. № 34(73). C. 5-25.

4. Гмыря Л.Б., Шихалиев Ш.Ш., Шехмагомедов М.Г., Кузеева 3.3. Керамический кувшин с оттиском текста айата Суры Корана из Южного Дагестана (XII в.) // Вестник Дагестанского научного центра. 2015. № 56. C. $28-35$.

5. Гмыря Л.Б., Корженков А.М., Овсюченко А.Н., Ларъков А.С., Рогожин Е.А. Вероятные полеосейсмические деформации на Рубасском археологическом памятнике середины VI в. Южный Дагестан // Геофизические процессы и биосфера. 2019. Т. 18. № 3. C. 91-103.

6. Gmyrya L.B., Korzhenkov A.M., Ovsyuchenko A.N., Larkov A.S., Rogozhin E.A. Probable Paleoseismic Deformations at the Rubas Archeological Site, Mid-6th Century AD, South Dagestan // Izyestiya, Atmospheric and Oceanic Physics, 2019, Vol. 55, No. 10, pp. 15471558. Pleiades Publishing, Ltd., 2019. Russian, 2019, published in Geofizicheckie Protsessy I Biosfera, 2019, Vol. 18, No. 3, pp. 91-103.

7. Пахомов E.A. Крупнейшие памятники сасанидского строительства в Закавказье // Проблемы истории материальной культуры. 1933. № 9-10. C. 39-46.

8. Тревер К.В. Очерки по истории и культуре Кавказской Албании. IV в. до н.э. - VII в. н.э. М.; Л., 1959. - 391 с.

9. Алиев А.А., Алиев И.Н., Гаджиев М.С., Гейтнер М.Г., Кол Ф.Л., Магомедов Р.Г. Новые исследования Гильгильчайской оборонительной стены // Проблемы истории, филологии и культуры. 2004. № 14. С. 441-465.

10. Gadžiev M.S., Kudrjucev A.A. Steinmetzzeichen aus dem 6. Jahrhundert in Derbent // Archäologische Mitteilungen 
11. Vus OV. Early Byzantine Limes in the Northern Black Sea Region: Organization and Structure of Engineering Defense. Byzantine Times. Moscow. 2013, 72(97): 227-246.

12. Ovcharov D. Bulgarians and Romanians on the Lower Danube in the early Middle Ages (according to archaeological data): trans. fromBulg. History in Bulgarian: crooked and falsified. Sofia, 2002. p. 170-200. (In Russ)

13. Gmyrya LB. The land of the Huns at the Caspian Gates. Makhachkala: Dagknigizdat, 1995. (In Russ)

14. Gmyrya LB. The descendants of the Huns in the steppes of South-Eastern Europe. The history of the Tatars from the ancient times (in 7 volumes). Vol. I. Peoples of the steppe Eurasia in ancient time. S. Klyashtoryny (ed.). Kazan: Rukhiyat, 2002. (In Russ)

15. Gmyrya LB. The Great Walls of the East Caucasus. Anti-civilization aspect of their significance in the global historical process. 3rd International congress on ancient archeology of Eurasian steppes "Between the East and the West: the shift of cultures, technologies and empires". N.N. Kradin, A.G. Sitdikov (eds.). Vladivostok: Dalnauka, 2017. aus Iran und Turan. Hrsg. vom Deutschen Archäologischen Institut Eurasien-Abteilung, AuBenstelle. Teheran. Bd. 33. Berlin:Reimer, 2001. pp. 357-390.

11. Вус O.В. Ранневизантийский Limes в Северном Причерноморье: организация и структура инженерной обороны // Византийский временник. М., 2013. Т. 72(97). С. 227-246.

12. Овчаров Д. Болгары и румыны на Нижнем Дунае в Раннем Средневековье (по археологическим данным): пер. с болг. // История на българите: изкривявания и фалшификации. София, 2002. С. 170-200.

13. Гмыря Л.Б. Страна гуннов у Каспийских ворот. Махачкала. Даг. кн. изд-во. 1995. $-228 \mathrm{c}$.

14. Гмыря Л.Б. Наследники гуннов в степях юго-восточной Европы // История татар с древнейших времен (в семи томах). Том I. Народы степной Евразии в древности / Ред. С. Кляшторный. Казань: Изд-во «Рухият», 2002. $-551 \mathrm{c}$.

15. Гмыря Л.Б. Великие стены Восточного Кавказа. Антицивилизационный аспект их значимости в мировом историческом процессе // III Международный конгресс средневековой археологии Евразийских степей «Между Востоком и Западом: движение культур, технологий и империй». Отв. ред. Н.Н. Крадин, А.Г. Ситдиков. Владивосток: Дальнаука, 2017. - 320 c.

Статья поступила в редакцию 10.10.2021 2. 